\title{
Aerosol size distribution seasonal characteristics measured in Tiksi, Russian Arctic
}

\author{
E. Asmi ${ }^{1}$, V. Kondratyev ${ }^{1,2}$, D. Brus ${ }^{1}$, T. Laurila ${ }^{1}$, H. Lihavainen ${ }^{1}$, J. Backman ${ }^{1}$, V. Vakkari ${ }^{1}$, M. Aurela ${ }^{1}$, J. Hatakka ${ }^{1}$, \\ Y. Viisanen ${ }^{1}$, T. Uttal ${ }^{3}$, V. Ivakhov ${ }^{4}$, and A. Makshtas ${ }^{5}$ \\ ${ }^{1}$ Atmospheric Composition Research, Finnish Meteorological Institute, Helsinki, Finland \\ ${ }^{2}$ Yakutian Service for Hydrometeorology and Environmental Monitoring, Tiksi, Russia \\ ${ }^{3}$ National Oceanic and Atmospheric Administration, Boulder, CO, USA \\ ${ }^{4}$ Voeikov Main Geophysical Observatory, St. Petersburg, Russia \\ ${ }^{5}$ Arctic and Antarctic Research Institute, St. Petersburg, Russia
}

Correspondence to: E. Asmi (eija.asmi@fmi.fi)

Received: 1 June 2015 - Published in Atmos. Chem. Phys. Discuss.: 2 July 2015

Revised: 20 December 2015 - Accepted: 28 December 2015 - Published: 3 February 2016

\begin{abstract}
Four years of continuous aerosol number size distribution measurements from the Arctic Climate Observatory in Tiksi, Russia, are analyzed. Tiksi is located in a region where in situ information on aerosol particle properties has not been previously available. Particle size distributions were measured with a differential mobility particle sizer (in the diameter range of 7-500 $\mathrm{nm}$ ) and with an aerodynamic particle sizer (in the diameter range of $0.5-10 \mu \mathrm{m}$ ). Source region effects on particle modal features and number, and mass concentrations are presented for different seasons. The monthly median total aerosol number concentration in Tiksi ranges from $184 \mathrm{~cm}^{-3}$ in November to $724 \mathrm{~cm}^{-3}$ in July, with a local maximum in March of $481 \mathrm{~cm}^{-3}$. The total mass concentration has a distinct maximum in February-March of 1.72$2.38 \mu \mathrm{g} \mathrm{m}^{-3}$ and two minimums in June $\left(0.42 \mu \mathrm{g} \mathrm{m}^{-3}\right)$ and in September-October $\left(0.36-0.57 \mu \mathrm{g} \mathrm{m}^{-3}\right)$. These seasonal cycles in number and mass concentrations are related to isolated processes and phenomena such as Arctic haze in early spring, which increases accumulation and coarse-mode numbers, and secondary particle formation in spring and summer, which affects the nucleation and Aitken mode particle concentrations. Secondary particle formation was frequently observed in Tiksi and was shown to be slightly more common in marine, in comparison to continental, air flows. Particle formation rates were the highest in spring, while the particle growth rates peaked in summer. These results suggest two different origins for secondary particles, anthropogenic pollution being the important source in spring and
\end{abstract}

biogenic emissions being significant in summer. The impact of temperature-dependent natural emissions on aerosol and cloud condensation nuclei numbers was significant: the increase in both the particle mass and the CCN (cloud condensation nuclei) number with temperature was found to be higher than in any previous study done over the boreal forest region. In addition to the precursor emissions of biogenic volatile organic compounds, the frequent Siberian forest fires, although far away, are suggested to play a role in Arctic aerosol composition during the warmest months. Five fire events were isolated based on clustering analysis, and the particle mass and cloud condensation nuclei number were shown to be somewhat affected by these events. In addition, during calm and cold months, aerosol concentrations were occasionally increased by local aerosol sources in trapping inversions. These results provide valuable information on interannual cycles and sources of Arctic aerosols.

\section{Introduction}

The Arctic and northern boreal regions of Eurasia are changing rapidly as a consequence of increased human activities (Richter-Menge et al., 2006; Bond et al., 2013). Aerosol particles are one of the major climate forcers in the Arctic; they reflect and absorb the incoming solar radiation, modify the properties of clouds, and affect the surface albedo. Shindell and Faluvegi (2009) suggested that over two thirds of the 
observed Arctic surface temperature increase during the last decades is attributable to changes in concentrations of sulfate and black carbon (BC) aerosols.

Aerosol particles in snow- and ice-covered regions have specific climate impacts and feedback processes. Recent experimental evidence indicates that in pristine polar regions, the aerosol-cloud feedback can be extremely sensitive to aerosol numbers. It was shown that even a small increase in particle number leads to an increased cloud droplet number concentration, thus affecting the cloud radiative properties but also decreasing the cloud maximum supersaturation (Asmi et al., 2012). The Arctic clouds, contrary to those occurring at lower latitudes, can enhance overall warming of the surface (Walsh and Chapman, 1998; Mauritsen et al., 2011). To understand these processes, information on aerosol sizes is of particular interest; however, only a few long-term studies of aerosol number and size distributions from the Arctic locations exist (Bodhaine, 1989; Tunved et al., 2013). These have suggested a rather clear seasonal cycle of increased particle number and mass in early spring as a consequence of the Arctic haze phenomenon (Mitchell, 1957). Currently, the commonly used global and chemical transport models consistently fail in predicting the Arctic aerosol seasonal cycles and also encounter problems in capturing the composition and quantities of polar aerosols (Bourgeois and Bey, 2011; Liu et al., 2012; Bond et al., 2013; Eckhardt et al., 2015). Several studies suggest that this can be attributed to problems in the treatment of the aerosol transport in models and in particular in wet-scavenging processes (e.g., Liu et al., 2012). Some recent studies also indicate that a number of sources have been neglected (Hienola et al., 2013; Stohl et al., 2013; Stock et al., 2014). Eckhardt et al. (2015) compared the absorbing aerosol concentration measured in Tiksi, Russia, with several model results and found a major discrepancy throughout most of the year when the measured annual average concentration was 3 times that of the modeled concentration. This suggests a significant underestimation of black carbon concentration in emission inventories in Russia and also highlights the need of more detailed data from this region.

South of the Arctic on the Eurasian side is the vast Siberian region; knowledge about aerosol properties is particularly limited for this region. Recently, some studies documenting interannual variability in aerosol distributions from central Siberia were published, highlighting the importance of emissions of biogenic volatile organic compounds (BVOCs) on aerosol number and mass distributions in Siberian boreal forests (Heintzenberg et al., 2008, 2011; Chi et al., 2013). The impact of BVOC emissions on aerosol numbers and mass, and the temperature-related feedback connected with these emissions, is suggested by previous studies from other boreal regions (Tunved et al., 2006; Asmi et al., 2011; Paasonen et al., 2013); however, the relative importance of biogenic emissions for aerosols in the current and future warming Arctic is still an open question.
In this work, to fill these observational data gaps, we present long-term, high-quality observations from Arctic Siberia by introducing 4 years of continuous aerosol number size distribution observations from the Tiksi Hydrometeorological Observatory. We will quantify aerosol modal features, number and mass concentrations and analyze their temporal evolution in terms of source region controls and local weather parameters. Our goal is to assess the effects of BVOC emissions from Siberian boreal regions and wild fire emissions on the aerosol particle size distributions at Tiksi, as well as to describe the buildup of the Arctic haze in the region. Analysis of the nucleation mode aerosols indicates how secondary sources contribute significantly to the aerosol particle concentrations under different conditions in the Arctic.

\section{Methods}

\subsection{Site description}

A full history and a general overview of Tiksi International Hydrometeorological Observatory can be found in Uttal et al. (2013). The Tiksi meteorological observatory in northern Siberia $\left(71^{\circ} 36^{\prime} \mathrm{N}, 128^{\circ} 53^{\prime} \mathrm{E}\right)$ on the shore of the Laptev Sea has been operating since 1930s. As an International Polar Year (IPY) 2007-2008 activity, the observatory was further upgraded and joined the network of the International Arctic Systems for Observing the Atmosphere (IASOA; www. IASOA.org). The Tiksi observatory is run in collaboration with NOAA (National Oceanic and Atmospheric Administration), Roshydromet AARI (Arctic and Antarctic Research Institute) and MGO (The Voeikov Main Geophysical Observatory) units, the Yakutian Service for Hydrometeorology and Environmental Monitoring, and the FMI (Finnish Meteorological Institute). FMI activities in Tiksi were initiated in summer 2010 and include the aerosol number size distribution measurements presented here.

The city of Tiksi is situated on the Lena river delta, with a current population of about 5000. The meteorological observatory is located $5 \mathrm{~km}$ southwest of the city, from which it is separated by a hill, and is about $500 \mathrm{~m}$ from the Laptev sea (Figs. 1 and S1 in the Supplement). The airport of Tiksi is further north of the city and the station. The site under examination here is far north of the tree line and is surrounded by low tundra vegetation and a line of mountains in the south.

\subsection{Measurements}

Measurements of aerosol size distributions, along with many other atmospheric parameters (for these, see Uttal et al., 2013), were started in 5 July 2010. The aerosol number size distribution from 7 to $500 \mathrm{~nm}$ (and later from 3 to $800 \mathrm{~nm}$ ) is measured with a twin-differential mobility particle sizer (DMPS) system, and the distribution above $500 \mathrm{~nm}$ is measured with an aerodynamic particle sizer (APS model 3321, TSI Inc., USA). For further description of the instruments, 


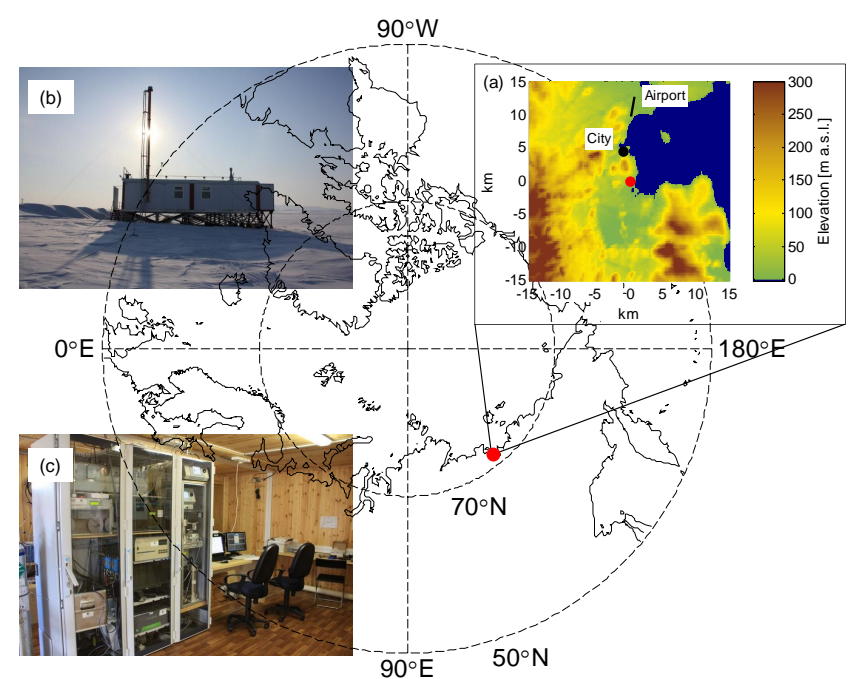

Figure 1. Location of the Tiksi measurement station. Panel (a): topographic map (United States Geological Survey, 2015 ${ }^{1}$ ) of the surroundings of the measurement site (station indicated by a red dot). Panel (b): the station as seen from outside. Panel (c): the station interior.

see Sect. 2.2.1. The time resolution of the DMPS measurements was set to $10 \mathrm{~min}$ and that of the APS to $5 \mathrm{~min}$.

Both of the instruments are attached to a stainless steel inlet tube with an outer diameter (O.D.) of $16 \mathrm{~mm}$ and inner diameter (I.D.) of $12 \mathrm{~mm}$. The tube is fixed just above the instrument rack and extends $2 \mathrm{~m}$ above the roof of the building (i.e., $6.5 \mathrm{~m}$ above the ground level). The APS is located directly below the inlet tube with a straight connection and a total APS line length of about $2.5 \mathrm{~m}$. The DMPS inlet length is $4-5 \mathrm{~m}$, and the theoretical diffusional losses for laminar tube flow during the particle transport are taken into account in the data inversion (Hinds, 1999).

The inlet tube is equipped with an inlet head of a fixed cutoff size of $10 \mu \mathrm{m}$ (BGI Inc, USA). The head also protects the instruments from snow, rain, and soil contaminants. Flow through the inlet is kept at a constant $1 \mathrm{~m}^{3} \mathrm{~h}^{-1}$ with an additional compensating flow, regulated depending on the total flow of all instruments. For example, when an aethalometer with a flow rate of $5 \mathrm{~L} \mathrm{~min}^{-1}$ was added online to the DMPS and APS in August 2010, the compensating flow was reduced from 10 to $5 \mathrm{~L} \mathrm{~min}^{-1}$. Heating (self-regulating) and insulation were added to the inlet tube in summer 2012, after two winters of relatively poor data coverage due to ice-related problems.

The flows and proper operation of all the instruments are fully checked twice a year during the station maintenance visits. Additionally, the automated flow, temperature, and pressure sensors allow the control of instruments and data

\footnotetext{
${ }^{1}$ United States Geological Survey, Global Multi-resolution Terrain Elevation Data 2010, available at http://earthexplorer.usgs. gov/; last access: 6 May 2015.
}

throughout the year. The station staff is trained to solve problems which might occur unexpectedly and they are also in charge of the regular weekly maintenance.

Data are transferred real-time to AARI via satellite connection and daily to NOAA and FMI servers and are quality checked weekly.

\subsubsection{Size distributions}

The twin-DMPS system used in Tiksi since 2010, as well as our data inversion procedure, are described thoroughly in Wiedensohler et al. (2012) and here only a brief summary is given.

The twin-DMPS consists of two identical DMPS systems: one equipped with a short Vienna-type differential mobility analyzer (DMA) to measure particle sizes from 7 to $115 \mathrm{~nm}$ and one with a medium-long Vienna-type DMA to measure particle sizes from 15 to $500 \mathrm{~nm}$. Both use a condensation particle counter (CPC model 3772, TSI Inc., USA) as a particle detector, calibrated to a cutoff size of $7 \mathrm{~nm}$ using silver nanoparticles and with an adjusted temperature difference between the CPC saturator and condenser of $23^{\circ} \mathrm{C}$. DMPS sheath flows are controlled by a blower (Ametek, USA) and regulated with a PID controller. The aerosol flow rate of $1 \mathrm{~L} \mathrm{~min}^{-1}$ and sheath flow rate of $6 \mathrm{~L} \mathrm{~min}^{-1}$ are used. The size range of DMPS measurements was extended up to $800 \mathrm{~nm}$ in 15 May 2012. Further extension of the measurement size range down to $3 \mathrm{~nm}$ was done in 3 July 2013, when the original CPC model 3772 was replaced with a CPC model 3776 (TSI Inc., USA). The CPC 3772 was then installed to measure the particle total number concentration. Flows of the short-DMPS system after this are 1.5 and $9 \mathrm{~L} \mathrm{~min}^{-1}$, for aerosol and sheath, respectively. The dryer is not used in front of the instruments since the sample air relative humidity $(\mathrm{RH})$ remains close to zero during the majority of the year, with the maximum measured so far being $30 \%$.

\subsubsection{Auxiliary weather parameters and black carbon}

Air temperature and relative humidity are measured by Vaisala HMP45D Pt100 and capacitive sensors. Solar radiation is monitored by a Kipp\&Zonen CMP3 pyranometer and air pressure by a Vaisala PMT16A attached to a Vaisala QML201 data logger. A Metek USA-1 sonic anemometer is used for wind and turbulence observations. Until July 2013, we used auxiliary meteorological data measured at the micrometeorological flux cabin located $250 \mathrm{~m}$ to the south of the station building. Beginning on 9 July 2013 , auxiliary data are from the station. In this new location, wind is observed at a $10 \mathrm{~m}$ tower instead of the earlier $3 \mathrm{~m}$ flux measurement mast. To study the homogeneity of wind observations at station and cabin sites, we excluded calm cases (wind speeds less than $1 \mathrm{~m} \mathrm{~s}^{-1}$ ) in the same way as was done for the other analyses here. Compared to the wind speed observations at the station, wind speed at the cabin was on aver- 
age $71 \%$ (correlation coefficient 0.93 ) and $79 \%$ (correlation coefficient 0.97 ) lower in summer and winter, respectively. Wind directions were within $30^{\circ}$ in 93 and $87 \%$ of the cases in summer and winter, respectively.

Black carbon at the station is measured with an aethalometer (Magee Scientific, model AE31). The instrument has seven wavelengths, of which that of $880 \mathrm{~nm}$ is used to determine the black carbon (BC) mass, assuming a mass absorption cross section of $16.6 \mathrm{~m}^{2} \mathrm{~g}^{-1}$. The wavelength of $880 \mathrm{~nm}$ was chosen since longer wavelength are less influenced by the presence of brown carbon, which is not investigated in detail here (Andreae and Gelencér, 2006; Kirchstetter and Thatcher, 2012). The equivalent BC mass concentrations of the aethalometer is used as such although there exists several different correction schemes for the data (Collaud Coen et al., 2010; Petzold et al., 2013). The most important part of the correction schemes is to compensate for the instrument response as the filter attenuation increases. However, no such general behavior was observed in the data, and this therefore justifies using the data without correction.

\subsection{Data analysis}

All the data are measured and presented in UTC. The solar midday in Tiksi is around 13:30 local time (22:30 UTC). No conversion to standard temperature and pressure (STP) was done, since the site is at sea level and the measurement temperature remained relatively stable around $20^{\circ} \mathrm{C}$.

\subsubsection{Data coverage}

Due to harsh winter conditions and the remoteness of the Tiksi site, in addition to instrument-related failures, some of the data were lost in particular during the first two winters (Fig. S2, Supplement). The overall data coverage in our DMPS measurements was $74 \%$, but an additional $36 \%$ of this coverage were lost in data cleaning. The data coverage for APS was $30 \%$, and for meteorological ( $T, \mathrm{RH}$, wind, and radiation) measurements it was $76 \%$.

\subsubsection{DMPS data inversion, cleaning, and quality checking}

DMPS data were inverted using measured flow rates and the default temperature of $293 \mathrm{~K}$ and a pressure of $1 \mathrm{~atm}$, using the routine as described in Wiedensohler et al. (2012). Briefly, the data inversion routine uses the charging probabilities defined by Wiedensohler (1989), and the transfer functions of Stolzenburg (1988) and takes into account the theoretical diffusion losses of particles in measurement lines and inside the DMAs; it also accounts for the calibrated CPC detection efficiencies.

As a first step, all data were inverted and manually checked for any instrument- or inversion-related failures. These data are here referred to as all the data available. As a second step, these data were cleaned to remove any local pollution, which was mainly related to activities in Tiksi city, north of the station. Therefore, the wind direction and speed were used as an indication of contamination, and all data captured during winds from the $315-45^{\circ}$ sector were removed, as well as those values that were measured at wind speeds $<1 \mathrm{~m} \mathrm{~s}^{-1}$. In addition to this, occasional short-term peaks, especially when occurring in Aitken mode sizes, were removed. These peaks might have been caused by different human activities in the vicinity of the station, for example staff being taken to the station in motorized vehicles.

For the period of about 10 months (3 July 2013-14 May 2014) of coincident DMPS and CPC measurements, the quality of data and that of the DMPS inversion routine were additionally verified by making a comparison of the DMPS total integrated number (in a size range of 7-500 nm) and the total number measured by the CPC 3772 . The median of the CPC number during the size-stepping period of $10 \mathrm{~min}$ of the overlapping DMPS measurements was used as a comparison. A least-square fit of DMPS versus CPC number as constrained with a zero-intercept forcing, resulted in a slope of 0.98 with a coefficient of determination, R-squared, value of 0.92 .

\subsubsection{Diameter and density correction to APS}

The APS measures the aerodynamic particle sizes, while the DMPS measures the particle mobility (which is equal to particle geometric size if the shape factor is assumed to be 1) sizes. The aerodynamic diameters of particles $\left(D_{\mathrm{a}}\right)$ are related to mobility diameters:

$D_{\mathrm{p}}=D_{\mathrm{a}} \sqrt{\frac{\rho_{0}}{\rho_{\mathrm{p}}}} \sqrt{\frac{C_{\mathrm{c}}\left(D_{\mathrm{p}}\right)}{C_{\mathrm{c}}\left(D_{\mathrm{a}}\right)}}$,

where $\rho_{0}$ is the density of $D_{\mathrm{a}}$, in this case the unit density of a sphere $\left(1 \mathrm{~g} \mathrm{~cm}^{-3}\right)$, and $\rho_{\mathrm{p}}$ is the density of $D_{\mathrm{p}}$. The square root of the ratio of the slip correction terms $\left(C_{\mathrm{c}}\right)$ can be approximated as unity here, since the underestimation due to this is very minor in the size range in question $\left(D_{\mathrm{p}}>500 \mathrm{~nm}\right)$.

To combine our observations we still need to approximate the particle density $\rho_{\mathrm{p}}$. As a first approximation, we used a value of $1.5 \mathrm{~g} \mathrm{~cm}^{-3}$, previously reported and largely used for northern Finnish boreal forest sites (Saarikoski et al., 2005; Viskari et al., 2012). The goodness of this approximation was also tested by matching the APS and DMPS data from the period of overlapping measurements (16 January 201326 November 2013). The APS data were merged with the time frame of the available DMPS measurements using averaging when several APS observations were available from the $10 \mathrm{~min}$ period of the DMPS measurement cycle. Furthermore, the highest and the lowest 10th percentiles (based on total concentration) were removed from both the DMPS and APS data, leaving $66 \%$ of the overlapping data available for analysis. The density correction to the APS changed the lowest measured diameter size from 500 to $410 \mathrm{~nm}$. 
The APS showed lower concentrations in the size range in which the instruments overlap (Fig. S3, Supplement). It is likely that the APS undercounts the particles in its lowest channels, while the DMPS correspondingly suffers from larger statistical errors in its highest channels where the number concentrations are low. Therefore, the three lowest channels of the APS and the highest of the DMPS were discarded from further analysis, leaving a comparison size range from 493 to $658 \mathrm{~nm}$ (lower and upper size limit). However, the scatter of these data resulted in a slope of $1.79\left(R^{2}=\right.$ $0.56)$, with the APS underestimating the particle concentration (Fig. S4, Supplement). The slope appeared to be slightly steeper in warm months (July-August), possibly indicating a decrease in particle density. However, since both of the instruments used are known to have problems in their overlapping size range, further corrections (e.g., a correction of a detection efficiency) were not done, and thus the coarse-mode aerosol concentration derived based on APS data should be interpreted as a lower limit estimate. All the APS data shown here are presented in mobility diameters, assuming a particle density of $1.5 \mathrm{~g} \mathrm{~cm}^{-3}$.

\subsubsection{Calculation of air mass back trajectories}

Air mass back trajectories at arrival levels of 100, 500, and $1000 \mathrm{~m}$ a.s.l. for Tiksi were calculated using a HYSPLIT 4 model (Draxler and Hess, 1997, 1998; Draxler, 1999). The National Weather Service's National Centers for Environmental Prediction (NCEP) Global Data Assimilation System (GDAS) was used as a meteorological data input for the HYSPLIT model runs. A new trajectory was started every $3 \mathrm{~h}$ calculating $120 \mathrm{~h}$ backwards. Trajectories calculated for different arrival heights generally showed very similar paths, and, for example, the overall calculated average fraction of air masses over the continent was $0.70,0.68$, and 0.69 for 100,500 , and $1000 \mathrm{~m}$ heights, respectively.

\subsubsection{Clustering of size distributions}

A cluster analysis technique was applied to divide particle size distributions into five mutually different but internally similar groups. The K-means clustering algorithm, previously described as an efficient and suitable method for clustering particle size distributions (Beddows et al., 2009), was used for minimizing the within-cluster variance (sum of squared Euclidean distances from cluster centers). The number of clusters was chosen based on several test runs with different numbers of clusters. The initial cluster centroid positions for the iterative algorithm were chosen randomly, which however, based on several consecutive runs did not affect the final cluster composition significantly.

\subsubsection{Analysis of new particle formation and growth}

The 4 years of DMPS measurements were analyzed for new particle formation events and their characteristics. Days with new particle formation (NPF) were identified from the data using the methodology as developed by Dal Maso et al. (2005). According to the methodology, any days when particles appear to below the $25 \mathrm{~nm}$ size range and form a growing mode are classified as event days. Those event days when uninterrupted growth of particles is detected starting at the smallest measurable size of $7 \mathrm{~nm}$ further belong to event class I. In contrast, class II events present more concentration fluctuations, and therefore it is not possible to calculate the particle growth rates or formation rates. Days of no growth or growth of the larger Aitken mode particles are classified as undefined days. Days with no particles at nucleation mode sizes are non-event days. Additionally, days with missing or bad data are defined as unclassified.

For class I events, the particle growth rates and formation rates were also calculated using the exact same method as in Asmi et al. (2011) for the analysis of the NPF in northern Finland. Particle growth rates $\left(\mathrm{nm} \mathrm{h}^{-1}\right)$ were calculated following the growing mode peak diameter and the particle formation rates (at $7 \mathrm{~nm}$ size) were calculated by following the increase in nucleation mode number concentration with time, with the mode maximum diameter being put in by the user. In contrast with the analysis presented by Kulmala et al. (2001), extra-modal coagulation losses were also taken into account, i.e., the losses of nucleation mode particles to bigger particle sizes. The particle atmospheric diameters were calculated using the hygroscopicity parameterization for boreal forest conditions as presented by Laakso et al. (2004).

\section{Results}

\subsection{Seasonal cycles of meteorological variables}

Meteorological conditions (Fig. 2) in Tiksi display large annual variability that is controlled by alternating periods of the polar night (19 November-24 January) and the midnight sun (11 June-3 August). With respect to the variables analyzed (i.e., temperature, $\mathrm{RH}$, radiation, winds, and air mass origin), the years from 2010 to 2014 had similar seasonal cycles. Median temperatures stayed above $0{ }^{\circ} \mathrm{C}$ for 4 months each year between June and September. This period was also characterized by the highest-frequency occurrence of marine air masses, the highest absolute values and variability in relative humidity, and the most stable wind speeds with median values ranging from 3 to $5 \mathrm{~m} \mathrm{~s}^{-1}$. A shift occurred in October with decreased solar insolation resulting in a temperature shift to below $0^{\circ} \mathrm{C}$. RH decreases were correlated with the decreasing temperature until January-February, after which the increasing solar radiation resulted in an increasing temperature and RH. The cold month winds were primarily continental, with a low-frequency occurrence of marine air masses. October through December, very high wind speeds occurred with half hour averages of up to $20 \mathrm{~m} \mathrm{~s}^{-1}$ indicating stormy weather conditions. January through March was the 


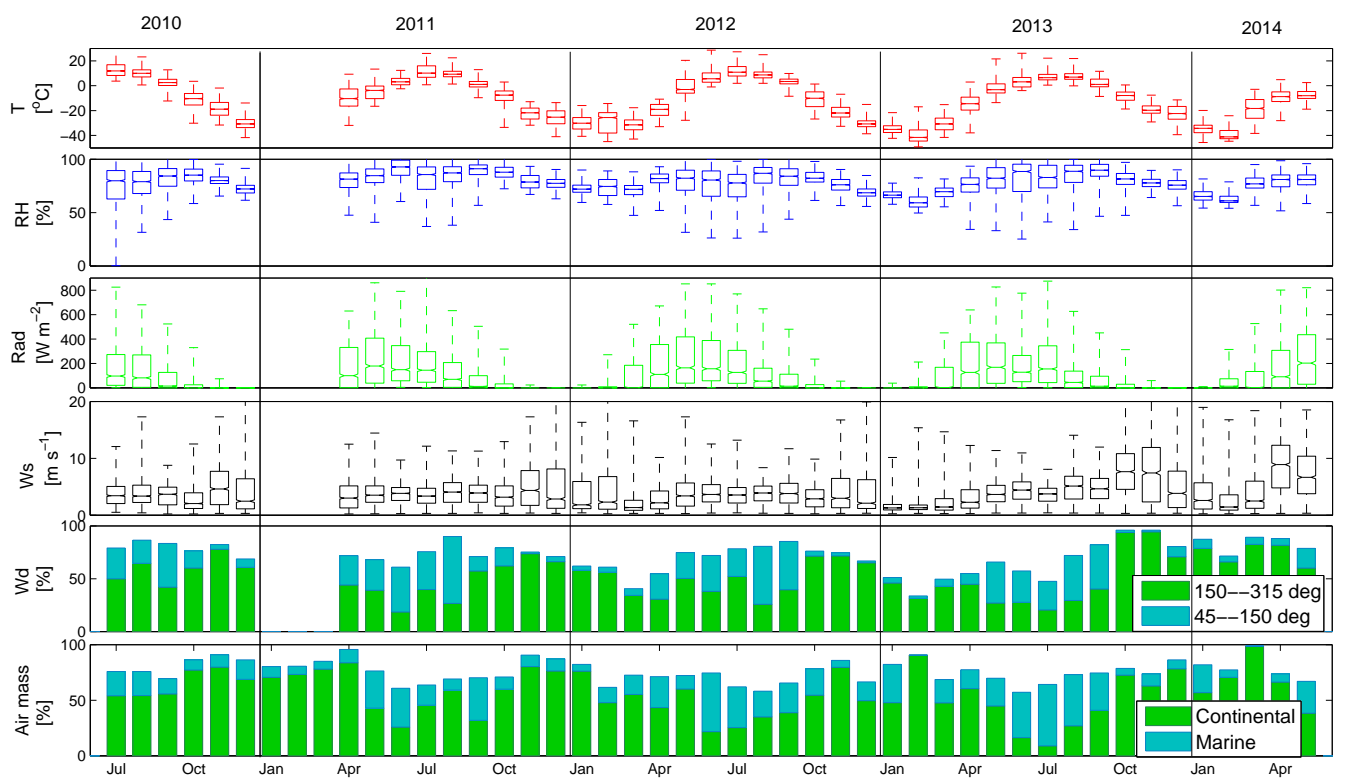

Figure 2. Summary of the meteorological conditions during the measurements. The panels $1-4$ (from top to down) depict temperature, relative humidity $(\mathrm{RH})$, global radiation, and wind speed, with bars showing extremes, quartiles and median values for each of the monthly parameters. Wind direction (panel 5) is expressed as percentages from the $45-315^{\circ}$ sector (marine sector) and from the $150-315^{\circ}$ sector (continental sector), leaving out the sector defined as polluted. Air mass origin (panel 6) is presented as percentage of continental ( $\geq 70 \%$ during preceding $120 \mathrm{~h}$ ) and marine ( $\geq 70 \%$ during preceding $120 \mathrm{~h}$ ) air masses, leaving out the mixed air masses. Also note that RH is expressed as the ratio of the water vapor pressure to the saturation water vapor pressure over water, which is a meteorological convention. In freezing winter conditions, condensation will occur at a lower relative humidity than $100 \%$ (over water) when the vapor is saturated over ice.

calmest period of the year, with median wind speeds between 1 and $3 \mathrm{~m} \mathrm{~s}^{-1}$. A shift in weather conditions occurred in April-May with increasing temperatures and stronger winds and the onset of more frequent marine air flow. Precipitation data from the Russian Roshydromet weather observations for years 2010-2014 were examined. During the analysis period, most precipitation occurred in July-August when the monthly average precipitation amounts were $>50 \mathrm{~mm}$. The driest seasons were February-May and October-November when the monthly average precipitation was $<20 \mathrm{~mm}$.

\subsection{Temporal variability in aerosol numbers and mass}

The total particle number concentrations (Fig. 3 and Table 1) showed two annual maxima in March and in July. For further details on this annual cycle, the particle size distributions were further divided into four characteristic modes: nucleation $(7-25 \mathrm{~nm})$, Aitken $(25-100 \mathrm{~nm})$, accumulation (100$500 \mathrm{~nm}$ ), and coarse (>410 $\mathrm{nm}$ from APS, when available). The annual cycle of each of these modes was analyzed separately. It can be seen that for the nucleation and Aitken mode particles the July maxima are the highest in number, whereas for the accumulation and coarse-mode particles the March maxima are higher. The particle mass concentration maxima in March became even more dominant and persisted through the months of late winter and spring (Fig. 4 and Table 1). This indicates the significant influence of Arctic haze, which primarily increases the larger particle number and mass concentration, suggesting impacts via indirect aerosol effects and atmospheric visibility. Similar behavior could also be seen in seasonal cycles of size distributions, where the Aitken mode was the most dominant only during June-August and a strong accumulation mode was observed in spring months (Fig. S5, Supplement).

Compared to the aerosol number size distributions measured in northern Finland at the Pallas and Värriö Arctic sites (Laakso et al., 2003; Tunved et al., 2003), the distributions in Tiksi show similar seasonal variability but with lower concentrations throughout the year. Instead, compared to measurements at higher-latitude Arctic sites at Barrow and Zeppelin, the number concentration in Tiksi is higher especially during spring and summer (Bodhaine, 1989; Tunved et al., 2013). The mass concentrations in Tiksi present a similar annual variability as those measured at the Barrow and Zeppelin sites, but a quantitative comparison between them was difficult due to different methods and size ranges used (Quinn et al., 2002; Tunved et al., 2013).

Nucleation mode particles are indicative of the secondary production processes taking place in the Arctic. A clear minimum in nucleation mode concentration was observed in January. Concentration increased again with the increasing seasonal solar radiation, indicating a photochemically driven 


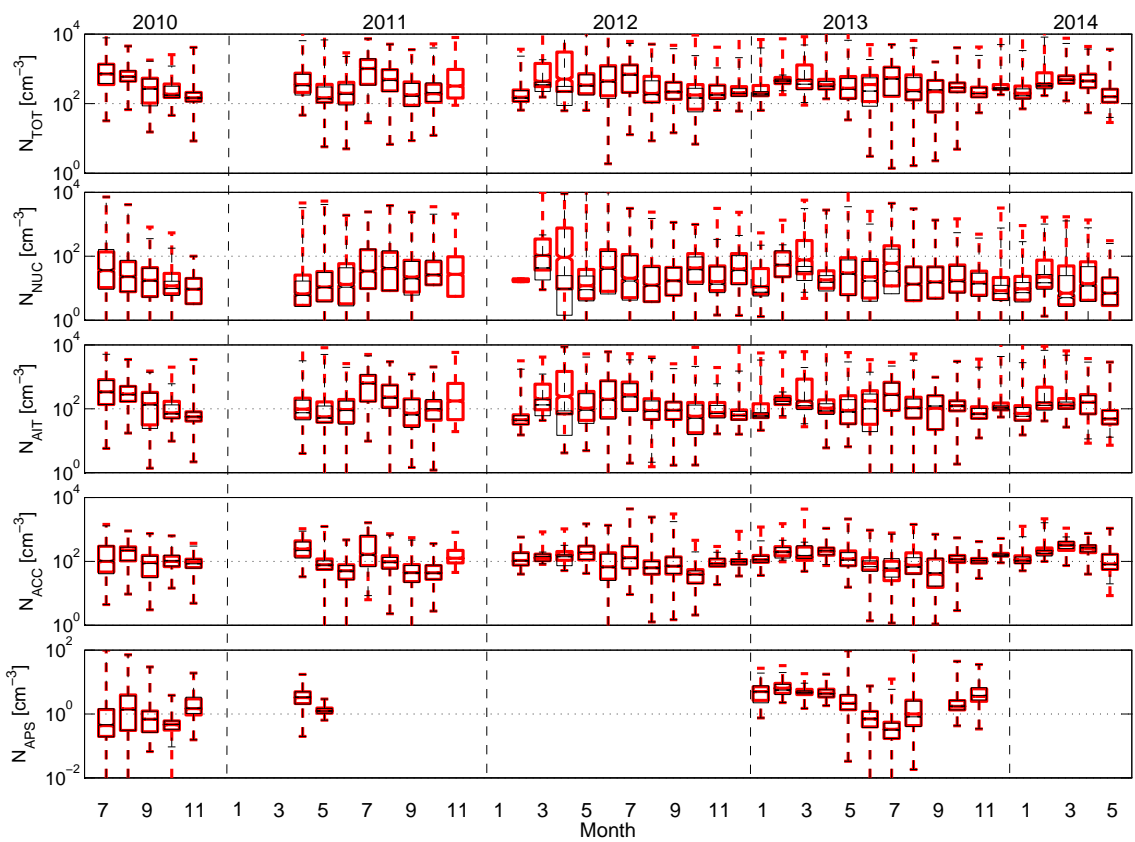

Figure 3. Temporal variability in aerosol total $(7-500 \mathrm{~nm})$, nucleation mode $(7-25 \mathrm{~nm})$, Aitken mode $(25-100 \mathrm{~nm})$, accumulation mode $(100-500 \mathrm{~nm})$, and coarse-mode ( $>410 \mathrm{~nm}$ ) number concentration, from top to bottom, respectively. Red bars show quartiles for each month of data available, and whiskers show the extremes. Black bars are calculated equally but excluding data measured when wind speed was $<2 \mathrm{~m} \mathrm{~s}^{-1}$. Dotted black lines mark the boundary between years.

Table 1. Average and median number and mass concentrations for different months. The first column indicates the month and the second column $(N)$ the amount of data used in averaging for DMPS and APS instruments. The columns that follow present monthly average $\left(\bar{N}_{\text {TO }}\right.$, $\left.\bar{N}_{\mathrm{NU}}, \bar{N}_{\mathrm{AI}}, \bar{N}_{\mathrm{AC}}, \bar{N}_{\mathrm{CO}}, \bar{M}_{\mathrm{TO}}, \bar{M}_{\mathrm{CO}}\right)$ and median $\left(\widetilde{N}_{\mathrm{TO}}, \widetilde{N}_{\mathrm{NU}}, \widetilde{N}_{\mathrm{AI}}, \widetilde{N}_{\mathrm{AC}}, \widetilde{N}_{\mathrm{CO}}, \widetilde{M}_{\mathrm{TO}}, \widetilde{M}_{\mathrm{CO}}\right)$ values calculated for the total $(7-500 \mathrm{~nm})$, nucleation mode $(7-25 \mathrm{~nm})$, Aitken mode $(25-100 \mathrm{~nm})$, accumulation mode $(100-500 \mathrm{~nm})$, and coarse-mode $(>410 \mathrm{~nm})$ number and for DMPS and APS total mass.

\begin{tabular}{|c|c|c|c|c|c|c|c|c|}
\hline Month & $\begin{array}{r}N \text { (DMPS/APS) } \\
\text { (cases) }\end{array}$ & $\begin{array}{r}\bar{N}_{\mathrm{TO}}\left(\tilde{N}_{\mathrm{TO}}\right) \\
\left(\mathrm{cm}^{-3}\right)\end{array}$ & $\begin{array}{r}\bar{N}_{\mathrm{NU}}\left(\widetilde{N}_{\mathrm{NU}}\right) \\
\left(\mathrm{cm}^{-3}\right)\end{array}$ & $\begin{array}{r}\bar{N}_{\mathrm{AI}}\left(\widetilde{N}_{\mathrm{AI}}\right) \\
\left(\mathrm{cm}^{-3}\right)\end{array}$ & $\begin{array}{r}\bar{N}_{\mathrm{AC}}\left(\widetilde{N}_{\mathrm{AC}}\right) \\
\left(\mathrm{cm}^{-3}\right)\end{array}$ & $\begin{array}{r}\bar{N}_{\mathrm{CO}}\left(\widetilde{N}_{\mathrm{CO}}\right) \\
\left(\mathrm{cm}^{-3}\right)\end{array}$ & $\begin{array}{r}\bar{M}_{\mathrm{TO}}\left(\tilde{M}_{\mathrm{TO}}\right) \\
\left(\mu \mathrm{g} \mathrm{m}^{-3}\right)\end{array}$ & $\begin{array}{r}\bar{M}_{\mathrm{CO}}\left(\tilde{M}_{\mathrm{CO}}\right) \\
\left(\mu \mathrm{g} \mathrm{m}^{-3}\right)\end{array}$ \\
\hline 1 & $4534 / 1734$ & 469 (200) & $36(10)$ & 297 (69) & 139 (112) & $5.3(5.0)$ & $1.38(1.24)$ & $1.60(1.07)$ \\
\hline 2 & $4070 / 1680$ & 639 (329) & $83(27)$ & 370 (119) & $222(182)$ & $7.4(6.3)$ & $2.03(1.72)$ & $1.72(1.64)$ \\
\hline 3 & $4825 / 2472$ & $762(481)$ & 146 (19) & $358(140)$ & $276(267)$ & $5.0(4.8)$ & $2.60(2.38)$ & $1.69(1.36)$ \\
\hline 4 & $7470 / 7512$ & 725 (396) & $130(14)$ & $341(123)$ & $258(222)$ & $4.3(4.0)$ & $2.18(1.89)$ & $1.74(1.31)$ \\
\hline 5 & $9903 / 6028$ & $529(222)$ & 89 (12) & $259(69)$ & 185 (113) & $3.5(1.8)$ & $1.59(0.96)$ & $1.18(0.70)$ \\
\hline 6 & $7776 / 4656$ & $620(327)$ & $142(26)$ & 338 (147) & $144(71)$ & $1.2(0.7)$ & $0.95(0.42)$ & $0.34(0.24)$ \\
\hline 7 & $10701 / 9267$ & $970(724)$ & $172(35)$ & $567(343)$ & $241(102)$ & $1.0(0.4)$ & $1.94(0.60)$ & $1.01(0.32)$ \\
\hline 8 & $11570 / 9572$ & $590(383)$ & 111 (19) & $322(161)$ & $160(90)$ & $4.3(1.1)$ & $1.41(0.56)$ & $1.15(0.48)$ \\
\hline 9 & $12651 / 6606$ & $324(222)$ & $61(18)$ & $160(98)$ & $105(60)$ & $1.0(0.7)$ & $0.83(0.36)$ & $0.74(0.46)$ \\
\hline 10 & $11950 / 7627$ & 302 (227) & $64(21)$ & $150(98)$ & $90(76)$ & $1.5(1.1)$ & $0.70(0.57)$ & $1.39(0.45)$ \\
\hline 11 & $8534 / 9910$ & $280(184)$ & $38(15)$ & $143(68)$ & $106(98)$ & $4.0(3.1)$ & $1.04(0.94)$ & $1.70(0.83)$ \\
\hline 12 & $2891 / 0$ & 415 (253) & $71(23)$ & $220(84)$ & $126(116)$ & - & $1.35(1.33)$ & - \\
\hline
\end{tabular}

process. Despite the high particle mass during the Arctic haze period, secondary production of particles also appeared to take place as soon as solar radiation was available. This is the opposite of what is seen at the high-latitude Arctic sites of Barrow and Zeppelin (Bodhaine, 1989; Tunved et al., 2013) but similar to what is observed at a continental norther Finnish Arctic site, Pallas (Asmi et al., 2011). The origin of the nucleating and condensing vapors may therefore be connected with regional continental sources in addition to what is contained in the haze itself. However, the long-rangetransported haze aerosols are also likely to be important for the secondary particle formation and growth process since after the dissipation of Arctic haze later in the spring, the nucleation mode concentrations decrease. A second nucleation mode maximum follows in summer, likely attributable to vegetation-related biogenic sources. 


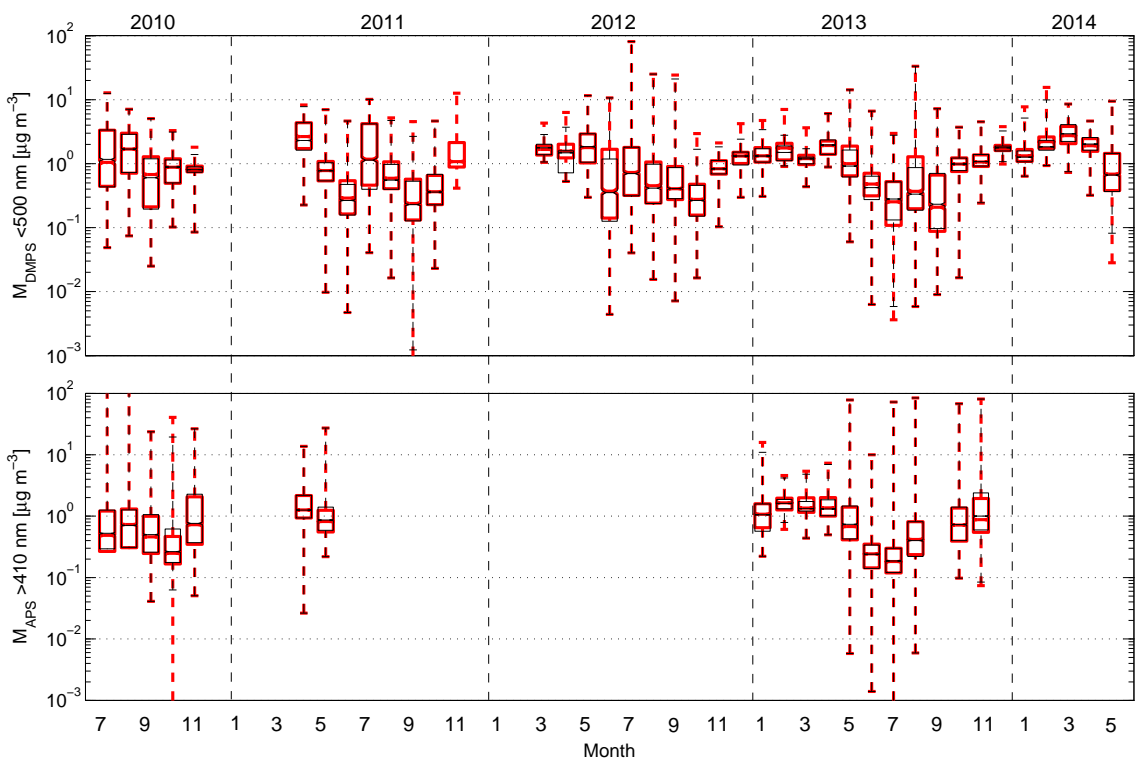

Figure 4. Temporal variability in aerosol total $(7-500 \mathrm{~nm})$ and coarse-mode $(>410 \mathrm{~nm})$ mass concentration in top and bottom panel, respectively. Red bars show quartiles for each month of data available, and whiskers show the extremes. Black bars are calculated equally but excluding data measured when wind speed was $<2 \mathrm{~m} \mathrm{~s}^{-1}$. Dotted black lines mark the boundary between years.

\subsection{Aerosol size distributions clusters}

In addition to the seasonal cycles of aerosol size distribution modes, a number of factors could potentially produce a specific type of number or mass size distributions. To elucidate any specific size distribution types and to study the impact of different environmental conditions on the modal characteristics of aerosol size distributions, we used cluster analysis as described in section 2.3.5. For this, the qualitycontrolled DMPS data (diameter range from 7 to $500 \mathrm{~nm}$ ) were clustered into five mutually dissimilar groups using the methodology explained in section 2.3.5. A median of $1.5 \mathrm{~h}$ distributions was used in order to capture the typical features corresponding to the different air mass types $(3 \mathrm{~h}$ time resolution) as well as to the variable meteorological parameters ( $0.5 \mathrm{~h}$ time resolution).

As a result of this clustering, most of the data appear to fall into a category of bimodal number size distributions, with maxima in Aitken and accumulation modes at sizes 50-70 and $200 \mathrm{~nm}$, respectively (Fig. 5a). Cluster 1 had the highest number concentration, with elevated concentrations especially in Aitken mode. An increase in Aitken mode aerosols indicates the proximity of local sources in addition to long-range transport represented by the accumulation mode. Looking at the meteorological parameters in Table 2, it can be seen that this type of size distributions occurred during cold winter days and they coincided with elevated black carbon (BC) concentrations, thereby indicating strong inversions trapping local pollutants originating in combustion sources. Winds were calm and air masses mainly continental, as was the case during most of the winter. However,
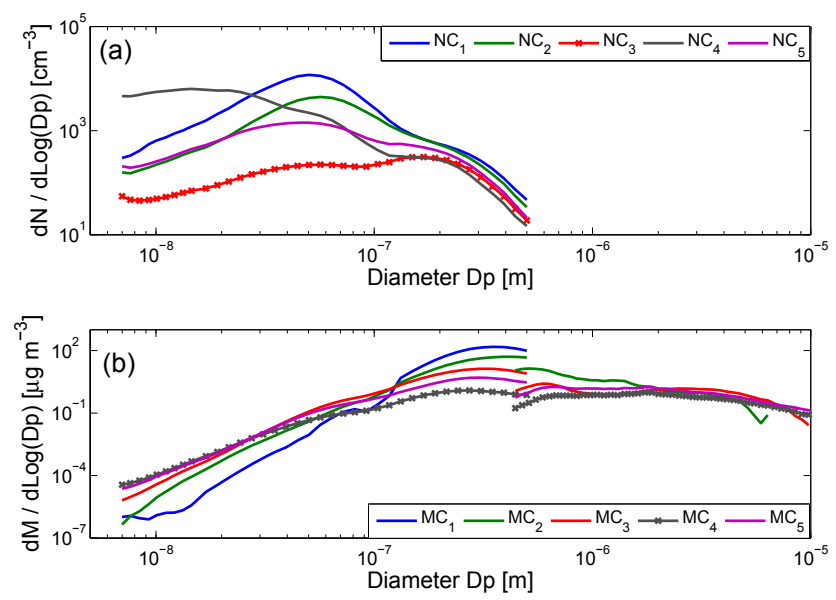

Figure 5. Average particle (a) number and (b) mass size distributions for different clusters (nos. 1-5). Crosses mark the most common cluster type found in both panel (a) and (b). In panel (b) the APS mass size distributions (at $>410 \mathrm{~nm}$ sizes) belonging to each of the clusters are also presented for times when they are available.

size distributions representative of cluster 1 are rare, and only 70 cases were identified in our analysis. Cluster number 2 , on the other hand, which also presents elevated number concentrations but clearly less severe pollution episodes, was more common and present also in other seasons. In summer, aged biomass burning aerosols could be included in this cluster type. This was also the cluster that showed the most continental influence. The remaining clusters, numbers 3-5, represent more clean air masses with no local influences, as seen 
Table 2. Total particle number concentration $(N)$, temperature $(T), \mathrm{RH}$, solar radiation (Rad), wind speed (Ws), percentage over continental areas (Cont), and black carbon mass concentration (uncorrected) (BC) for different size distribution clusters (numbers 1-5, referring to Fig. 5a). Number of cases available for each cluster is shown in parenthesis below the cluster number. For different variables, both the average (upper row) and median (lower row) are calculated, and for total number the standard deviation is also presented.

\begin{tabular}{lrrrrrrr}
\hline $\begin{array}{l}\text { Cluster no. } \\
\text { cases })\end{array}$ & $\begin{array}{r}N \\
\left(\mathrm{~cm}^{-3}\right)\end{array}$ & $\begin{array}{r}T \\
\left({ }^{\circ} \mathrm{C}\right)\end{array}$ & $\begin{array}{r}\mathrm{RH} \\
(\%)\end{array}$ & $\begin{array}{r}\mathrm{Rad} \\
\left(\mathrm{W} \mathrm{m}^{-2}\right)\end{array}$ & $\begin{array}{r}\text { Ws } \\
\left(\mathrm{m} \mathrm{s}^{-1}\right)\end{array}$ & $\begin{array}{r}\text { Cont } \\
(\%)\end{array}$ & $\begin{array}{r}\mathrm{BC} \\
\left(\mathrm{ng} \mathrm{m}^{-3}\right)\end{array}$ \\
\hline 1 & $5967 \pm 2237$ & -18.2 & 69 & 136 & 2.1 & 75 & 360 \\
$(70)$ & 5272 & -25.6 & 67 & 16 & 1.4 & 84 & 327 \\
\hline 2 & $2490 \pm 749$ & -3.7 & 67 & 181 & 2.8 & 77 & 214 \\
$(536)$ & 2360 & 8.9 & 67 & 80 & 1.8 & 86 & 145 \\
\hline 3 & $301 \pm 243$ & -5.9 & 80 & 106 & 5.0 & 63 & 127 \\
$(10187)$ & 240 & -3.4 & 81 & 22 & 4.3 & 69 & 44 \\
\hline 4 & $4941 \pm 2699$ & -5.6 & 70 & 402 & 2.7 & 51 & 123 \\
$(84)$ & 4214 & 2.5 & 71 & 410 & 2.5 & 43 & 86 \\
\hline 5 & $1193 \pm 443$ & 0.6 & 73 & 171 & 3.5 & 70 & 119 \\
$(1758)$ & 1104 & 6.6 & 76 & 88 & 2.9 & 75 & 46 \\
\hline
\end{tabular}

from their lower $\mathrm{BC}$ concentrations. Cluster number 3 was the most common cluster type observed, and it had both continental and marine influences and the lowest average number concentration $\left(301 \pm 243 \mathrm{~cm}^{-3}\right)$ of all the clusters. Cluster 4 was very specific to strong cases of secondary particle formation as seen by its high number concentration especially in nucleation mode. Interestingly, this cluster type contained mostly marine influences and was connected with high solar radiation, indicative of photochemical processes. It appears that nucleation is more common in marine as opposed to continental air masses; this phenomenon has been documented in previous studies (Sogacheva et al., 2008; Asmi et al., 2011). Compared to the other clean cluster types 5 and 3, cluster 4 had also the lowest values of RH. Increasing $\mathrm{RH}$ and decreasing radiation could be linked with cloudiness inhibiting nucleation (Sogacheva et al., 2008; Hamed et al., 2011). Interestingly, nucleation also seemed less likely with increasing wind speeds, which might be explained by more efficient dilution of the nucleating and condensing vapors or by the scavenging of nucleating clusters. This further implies that nucleation at Tiksi is connected to sources near the surface, most likely to biogenic VOC emissions. As secondary aerosols are aged, the particle number concentrations decrease and move towards larger sizes, which appear to be represented in the remaining cluster number 5. Secondary particle formation as a source of aerosols in Tiksi will be further analyzed in the following section.

A similar clustering analysis was done for the mass size distributions, with an assumed particle density of $1.5 \mathrm{~g} \mathrm{~cm}^{-3}$ (Fig. 5b and Table 3). APS data were not used in clustering due to poor data coverage; however, the results for coarse mode (when available) are presented.

The two first mass clusters, numbers 1 and 2, represent cases of extremely high mass concentrations, with averages of 52.1 and $18.4 \mu \mathrm{g} \mathrm{m}^{-3}$ (from DMPS only), respectively, and also elevated $\mathrm{BC}$ with concentrations up to $2 \mu \mathrm{g} \mathrm{m}^{-3}$. These clusters are characterized by strong continental influences and high average temperatures, indicating that they occur in summer continental air flows. Cluster 1 occurred only on 9 and 11 July 2012 and represents a strong case of longrange transport of biomass burning (BB) aerosols from the southern Yakutian region, as indicated by MODIS active fire records combined with back-trajectory calculations. Further, those days which make up cluster 2 are 26 July 2012, 1-2 August 2012, 25-26 September 2012, and 12-13 August 2013. For all these days, the back-trajectory calculations also indicated transport from southerly directions, where MODIS recorded forest fire activity; simultaneously, the measured $\mathrm{BC}$ concentration at Tiksi was elevated to around $1 \mu \mathrm{g} \mathrm{m}^{-3}$. Cluster 3 also has elevated mass concentrations and similar average BC-to-mass ratios to clusters 1 and 2. Cluster 3 occurred both in early spring and in summer and showed an average mass concentration of $5.8 \mu \mathrm{g} \mathrm{m}^{-3}$. This is less than the concentrations characterizing the biomass burning episodes, yet clearly higher than concentrations typical to Tiksi. The average temperature for cluster 3 was high $\left(6.5^{\circ} \mathrm{C}\right)$, values of global radiation were the highest and $\mathrm{RH}$ was the lowest of all the clusters. It therefore seems likely that this cluster represents summer continental air masses that were strongly affected by the biogenic sources and the secondary particle formation. Since the process of secondary particle formation from biogenic precursors is dependent on light providing the atmospheric oxidizing capacity, the conditions of high radiation and low RH (indicating low cloudiness) are favorable to this process (Hamed et al., 2011). If continental clusters typically have high mass concentrations, cluster 4 has the lowest mass concentration and is representative of very clean marine air. It occurred year-round but was the most prevalent during 
Table 3. Total particle mass concentration from DMPS data $(M)$, from APS data $\left(M_{\text {APS }}\right)$, temperature $(T)$, RH, solar radiation $(\operatorname{Rad})$, wind speed (Ws), percentage over continental areas (Cont), and black carbon mass concentration (uncorrected) (BC) for different size distribution clusters (numbers 1-5, referring to Fig. 5b). Number of cases available for each cluster is shown in parenthesis below the cluster number, and the number of cases from APS is shown after this. For different variables, both the average (upper row) and median (lower row) are calculated, and for total number the standard deviation is also presented.

\begin{tabular}{lrrrrrrrr}
\hline $\begin{array}{l}\text { Cluster no. } \\
(\text { cases/APS })\end{array}$ & $\begin{array}{r}M \\
\left(\mu \mathrm{g} \mathrm{m}^{-3}\right)\end{array}$ & $\begin{array}{r}M_{\text {APS }} \\
\left(\mu \mathrm{g} \mathrm{m}^{-3}\right)\end{array}$ & $\begin{array}{r}T \\
\left({ }^{\circ} \mathrm{C}\right)\end{array}$ & $\begin{array}{r}\mathrm{RH} \\
(\%)\end{array}$ & $\begin{array}{r}\mathrm{Rad}^{2} \\
\left(\mathrm{~W} \mathrm{~m}^{-2}\right)\end{array}$ & $\begin{array}{r}\text { Ws } \\
\left(\mathrm{m} \mathrm{s}^{-1}\right)\end{array}$ & $\begin{array}{r}\text { Cont } \\
(\%)\end{array}$ & $\begin{array}{r}\mathrm{BC} \\
\left(\mathrm{ng} \mathrm{m}^{-3}\right)\end{array}$ \\
\hline 1 & $52.1 \pm 10.7$ & - & 17.0 & 81 & 14 & 4.4 & 95 & 1674 \\
$(11 / 0)$ & 47.4 & - & 17.6 & 84 & 10 & 4.8 & 100 & 1551 \\
\hline 2 & $18.4 \pm 4.0$ & $7.8 \pm 0.6$ & 15.1 & 76 & 136 & 3.5 & 93 & 734 \\
$(43 / 16)$ & 19.2 & 7.8 & 17.0 & 85 & 68 & 3.2 & 100 & 745 \\
\hline 3 & $5.8 \pm 1.7$ & $1.7 \pm 1.3$ & 6.5 & 70 & 176 & 4.8 & 93 & 207 \\
$(676 / 269)$ & 5.3 & 1.4 & 7.8 & 74 & 100 & 4.4 & 100 & 135 \\
\hline 4 & $0.6 \pm 0.4$ & $0.8 \pm 1.4$ & -3.8 & 81 & 115 & 4.6 & 55 & 75 \\
$(8438 / 3001)$ & 0.5 & 0.4 & -0.5 & 82 & 30 & 4.0 & 50 & 21 \\
\hline 5 & $2.3 \pm 0.7$ & $1.6 \pm 2.1$ & -10.6 & 74 & 122 & 4.8 & 81 & 233 \\
$(3467 / 1009)$ & 2.1 & 1.1 & -9.5 & 74 & 20 & 3.7 & 98 & 132 \\
\hline
\end{tabular}

summer and autumn. The last cluster, number 5, represented a mix of continental and marine influence. Mass concentration was clearly increased compared to cluster 4, but, most interestingly, the ratio of black carbon was about twice as high as in any other cluster. Cluster 5 was mainly observed in early spring and is therefore likely to best represent the cases of Arctic haze and long-range transported aerosol influences.

\subsection{Secondary particle formation in Tiksi}

Secondary particle formation was also identified as an important source of aerosol in Tiksi, with one example of an event observed plotted in Fig. S6 in the Supplement. In Sect. 3.2 we have seen that nucleation mode concentrations were elevated particularly during spring and summer, which already provides an indication of the seasonal variability in particle formation. This process was further studied using the methodology described in Sect. 2.3.6.

Firstly, based on Dal Maso et al. (2005), we classified the measurement days into event, non-event, and undefined cases to study the frequency of the particle formation in different seasons. The monthly fraction of each of these classes is presented in Fig. 6 and shows that secondary particle formation in Tiksi is most frequent in early spring (March) and in summer (June-August). In March, a particle formation event was observed on nearly half of the days and in summer on $30-40 \%$ of the days. Events get less frequent towards autumn, similar to what is seen at the other Arctic site, Pallas, in northern Finland (Asmi et al., 2011). Also, the seasonal cycle of event frequency resembles that observed in Pallas; however, particle formation is seen almost twice as frequently in Tiksi as at the Pallas site (Asmi et al., 2011). Compared to another typical boreal forest site in southern Finland, the event

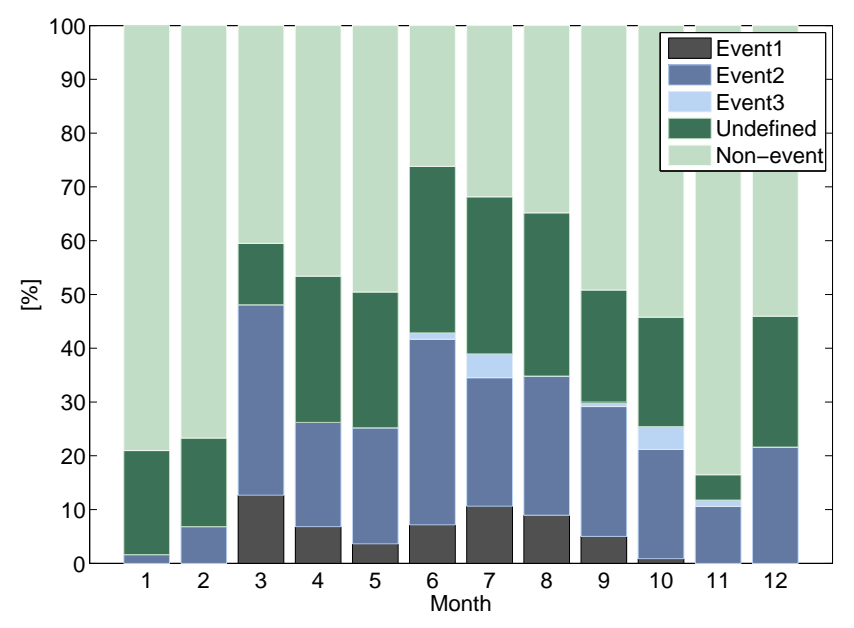

Figure 6. Classification of particle formation events into classes: 1 (strong event), 2 (weaker event but calculation of growth rate, GR, and formation rate, FR, possible), 3 (weak event, not possible to calculate GR and FR), undefined, and non-event day. Fractions of different types of events are shown for each month for the whole measurement period of about 4 years. More details on classification is found in Dal Maso et al. (2005).

frequencies in Tiksi are similar but differ slightly in seasonal cycle (Dal Maso et al., 2005). A similarly detailed analysis of the secondary particle formation has not been done for any other Arctic sites. However, based on aerosol modal variability, events at the Arctic Zeppelin station appear to follow a seasonal pattern similar to Tiksi and Pallas (Tunved et al., 2013).

Even if events in Tiksi were frequent, class 1 events starting at $7 \mathrm{~nm}$ size and showing a well-defined growing mode, 
Table 4. Secondary particle growth rates and formation rates in different months. First column indicates the month. The second column (GR) and the third column $\left(\mathrm{FR}_{7}\right)$ show the particle growth rate and formation rate parameters calculated for class 1 events only. The fourth column $\left(\mathrm{GR}_{\mathrm{ALL}}\right)$ and fifth column ( $\left.\mathrm{FR}_{\mathrm{ALL}}\right)$ present the growth rate and formation rate parameters calculated for all the events (class 2 included). Values in each column present the monthly averages with standard deviations followed by the medians in parenthesis.

\begin{tabular}{|c|c|c|c|c|}
\hline Month & $\begin{aligned} \overline{G R} \pm & \mathrm{SD}(\widetilde{G R}) \\
& \left(\mathrm{nm} \mathrm{h}^{-1}\right)\end{aligned}$ & $\begin{aligned} & \overline{F R}_{7} \pm \mathrm{SD}\left(\widetilde{F R}_{7}\right) \\
&\left(\mathrm{cm}^{-3} \mathrm{~s}^{-1}\right)\end{aligned}$ & $\begin{array}{r}\overline{G R}_{\mathrm{ALL}} \pm \mathrm{SD}\left(\widetilde{G R}_{\mathrm{ALL}}\right) \\
\left(\mathrm{nm} \mathrm{h}^{-1}\right)\end{array}$ & $\begin{array}{r}\overline{F R}_{\mathrm{ALL}} \pm \mathrm{SD}\left(\widetilde{F R}_{\mathrm{ALL}}\right) \\
\left(\mathrm{cm}^{-3} \mathrm{~s}^{-1}\right)\end{array}$ \\
\hline 1 & - & - & $1.1 \pm 0.0(1.1)$ & $0.02 \pm 0.00(0.02)$ \\
\hline 2 & - & - & $1.9 \pm 1.1(2.6)$ & $0.02 \pm 0.01(0.03)$ \\
\hline 3 & $1.5 \pm 0.3(1.4)$ & $0.40 \pm 0.32(0.22)$ & $1.2 \pm 0.7(1.0)$ & $0.25 \pm 0.24(0.19)$ \\
\hline 4 & $3.2 \pm 1.1(2.6)$ & $0.46 \pm 0.25(0.35)$ & $1.9 \pm 1.3(2.0)$ & $0.41 \pm 0.54(0.26)$ \\
\hline 5 & $3.3 \pm 0.8(3.4)$ & $0.90 \pm 0.50(0.89)$ & $1.7 \pm 1.5(1.1)$ & $0.21 \pm 0.42(0.01)$ \\
\hline 6 & $3.8 \pm 1.6(3.9)$ & $0.19 \pm 0.11(0.17)$ & $2.4 \pm 2.0(1.7)$ & $0.06 \pm 0.08(0.03)$ \\
\hline 7 & $4.8 \pm 2.7(3.9)$ & $0.30 \pm 0.24(0.19)$ & $3.6 \pm 2.5(3.1)$ & $0.14 \pm 0.18(0.09)$ \\
\hline 8 & $3.6 \pm 1.8(3.1)$ & $0.19 \pm 0.13(0.18)$ & $2.6 \pm 1.7(2.4)$ & $0.11 \pm 0.17(0.05)$ \\
\hline 9 & $4.0 \pm 1.6(4.5)$ & $0.10 \pm 0.07(0.09)$ & $1.6 \pm 1.5(1.1)$ & $0.04 \pm 0.05(0.01)$ \\
\hline 10 & $3.6 \pm 0.0(3.6)$ & $0.06 \pm 0.00(0.06)$ & $1.0 \pm 1.0(0.8)$ & $0.03 \pm 0.04(0.01)$ \\
\hline 11 & - & - & $0.8 \pm 0.4(1.0)$ & $0.01 \pm 0.01(0.01)$ \\
\hline 12 & - & - & $0.1 \pm 0.2(0.0)$ & $0.01 \pm 0.00(0.01)$ \\
\hline
\end{tabular}

were rare. For this reason the particle formation and growth rate parameters were also calculated for as many class 2 events as was feasible (the remaining events were classified as class 3; see Fig. 6). The interannual cycle of particle formation and growth rates was clear (Fig. 7 and Table 4). Growth rate maximum $\left(3.6 \mathrm{~nm} \mathrm{~h}^{-1}\right)$ was in July and the minimum $\left(0.1 \mathrm{~nm} \mathrm{~h}^{-1}\right)$ in December. Average growth rates of over $2 \mathrm{~nm} \mathrm{~h}^{-1}$ were only seen in summer months (June to August), suggesting an important role of biogenic emissions and photochemistry of those compounds which are responsible for the growth. This is similar to what has been observed at other boreal forest sites (e.g., Tunved et al., 2003; Dal Maso et al., 2005; Asmi et al., 2011). However, compared to other measurement sites closer to forested areas, particle growth rates in Tiksi were lower, and especially in autumn and winter, many examples of extremely low growth rates were observed. Nucleation mode particles with very limited growth have also been observed during the polar night in Antarctica (Järvinen et al., 2013; Weller et al., 2015).

The particle formation rates, instead, peaked in early spring, with a maximum value of $0.25 \mathrm{~cm}^{-3} \mathrm{~s}^{-1}$ observed in March. During winter, due to the absence of photochemistry, the particle formation rates were extremely small, being only around $0.01 \mathrm{~cm}^{-3} \mathrm{~s}^{-1}$. This annual cycle is in line with previous observations (e.g., Dal Maso et al., 2005; Asmi et al., 2011) and suggests that the same precursor compounds that lead to the formation of Arctic haze (i.e., SO2) also contribute to the regional-scale NPF events during spring.

Comparing the class 1 and class 2 formation and growth parameters, the class 1 events are stronger and also present higher particle growth rates (Table 4). For class 2 events, the formation rates presented are the lower estimates, while a new mode did not always appear at the lowest measurable

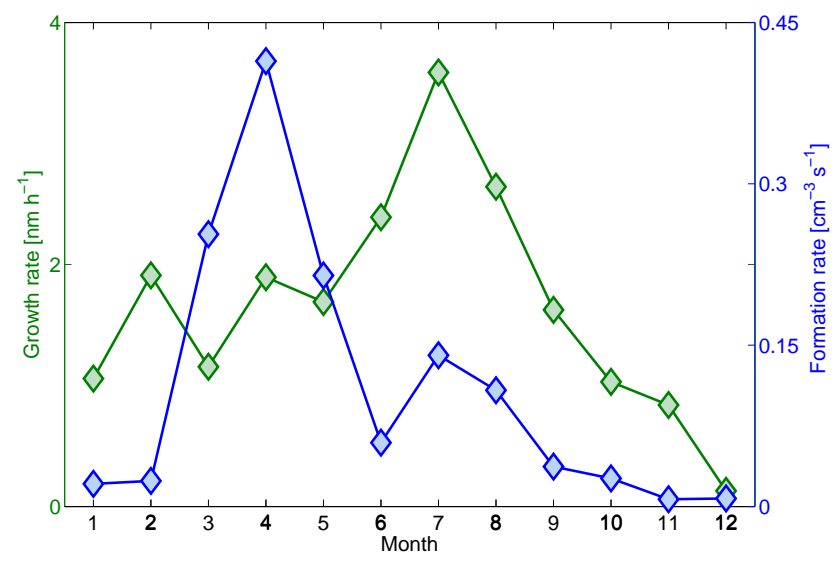

Figure 7. Monthly averages of particle growth rates (green) and formation rates (blue) for all class 1 and class 2 events. Note: particle formation rates were calculated for the lowest observed particle size, which was not, however, in all cases the lowest measurable size of $7 \mathrm{~nm}$.

$7 \mathrm{~nm}$ size. The seasonal cycle, however, is similar in both event classes.

Finally, the origin of air masses on event days and nonevent days was studied (Fig. 8). Indeed, it appears that on non-event days continental air flows were typical, while on event days such a tendency was not detected. On event days, coastal and marine air masses seemed to be slightly more common, as compared with non-event or undefined days. However, the origin alone did not allow us to different between days clearly enough for this to be a plausible explanation for particle formation, nor does it give a clear indication of the origin of the secondary particles, i.e., weather they are continental, coastal, or marine. 


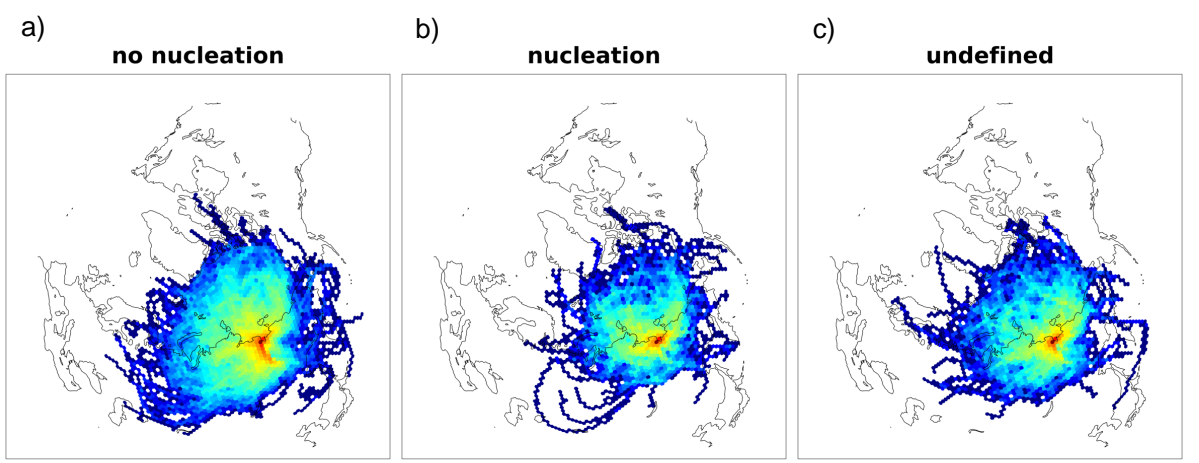

Figure 8. Back trajectories for air masses on non-event days (a), at the start of the NPF events (b), and at 11:00 LT in undefined days (c). Panels (a), (b), and (c) consist of 551, 259, and 244 individual trajectories, respectively. The trajectories were calculated using HYSPLIT 4 (Draxler and Hess, 1998) with an arrival height of $500 \mathrm{~m}$ above ground level calculated $120 \mathrm{~h}$ backwards in time. The color coding of the figure represents the number of trajectories that have passed over a geodesic hexagon on the map. Each trajectory coordinate was associated with a specific hexagon according to the minimum distance of a trajectory coordinate to the centroid of the grid cell. Each trajectory will pass over a number of grid cells. In order to circumvent weighting grid cells multiple times, each overpass is assigned only once to the grid cells that it will traverse.

\subsection{Continental biogenic sources driving the cloud condensation nuclei concentrations in summer}

Similar to previous observations in the boreal forest zone (Tunved et al., 2006; Asmi et al., 2011; Väänänen et al., 2013), observations at Tiksi indicate increasing submicron aerosol particle mass with increasing time over the continent (Fig. 9). The increase was larger by 1 order of magnitude when temperature exceeded $0^{\circ} \mathrm{C}$, although at temperatures $<0{ }^{\circ} \mathrm{C}$ some increase in aerosol mass could be still observed with longer time over the continent (Fig. 9b). This is expected considering the strong temperature dependency of biogenic VOC emissions (e.g., Guenther et al., 2006).

Another temperature-dependent feature affecting aerosols in Tiksi is the frequent Siberian fires (BB events). Results of the clustering analysis were used to assist in separating the four BB event cases observed in summer 2012 and the one $\mathrm{BB}$ event case in summer 2013 to isolate their impact on the overall result. The aerosol mass and number concentration addition with and without the inclusion of these events was analyzed separately.

Tunved et al. (2006) showed that the aerosol mass load over the Finnish Arctic site Pallas depends on the air mass time over the continent and follows a linear fit of $y=$ $0.014 x+0.12$, where $y$ represents the aerosol mass $\left(\mu \mathrm{g} \mathrm{m}^{-3}\right)$ and $x$ the time (h) spent over the continent, and AprilSeptember DMPS data for sizes $<450 \mathrm{~nm}$ were used for fitting. Fitting for the Tiksi data was also done using only summertime data and particle sizes $<500 \mathrm{~nm}$; the resulting fit of $y=0.018 x-0.05$ (Fig. 10a) indicates a similar or even higher mass increase over the Siberian continental region in comparison to the Nordic boreal forest. Exclusion of BB events decreased the slope from 0.018 to $0.016 \mu \mathrm{g} \mathrm{m}^{-3} \mathrm{~h}^{-1}$, yet it must be kept in mind that only the impact of the strongest five events was studied here. Additionally, Tiksi
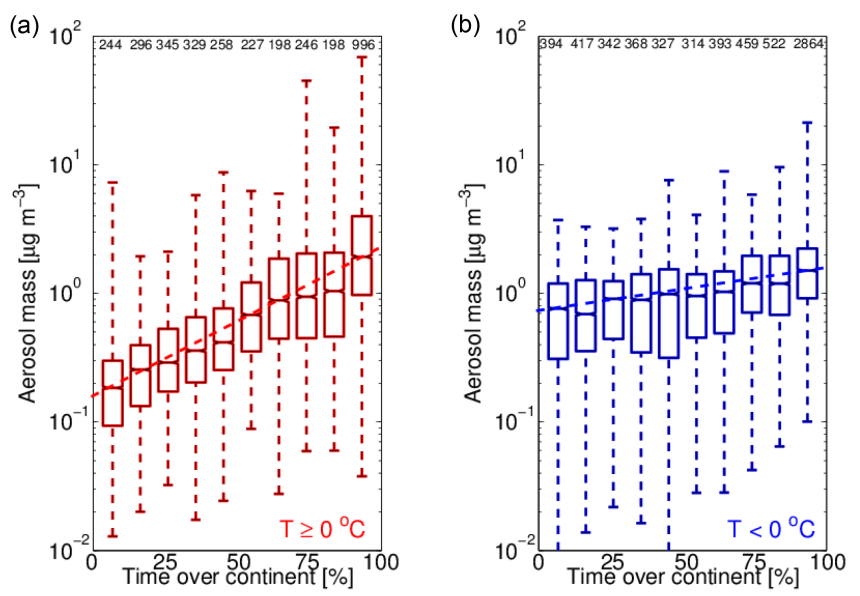

Figure 9. Aerosol total mass $(\leq 500 \mathrm{~nm})$ versus percentage of time the air mass spent over continental areas over the last $120 \mathrm{~h}$. Median mass concentration around each back trajectory (for every $3 \mathrm{~h}$ ) was used in calculations. In panel (a) the data measured at temperatures $\geq 0{ }^{\circ} \mathrm{C}$ are depicted in red, and in panel (b) the data measured at temperatures $<0{ }^{\circ} \mathrm{C}$ are shown. Boxes show the quartiles, with whiskers extending to extreme data points. Above each box is the number of cases used in calculations. Dashed red and blue lines are added to guide the eye.

data suggests an exponential rather than a linear dependence between aerosol mass and time over the continent. The exponential fit results in an improvement of $R_{2}$ values from 0.84 to 0.93 (and from 0.88 to 0.94 for no-BB cases). This might be a secondary effect of the observed temperature dependence of the continental air masses. Most continental air masses also had the warmest temperatures; therefore, it is likely that they originate further south, where there is denser vegetation as well as higher VOC emission rates (Guenther et al., 2006). 
(a)

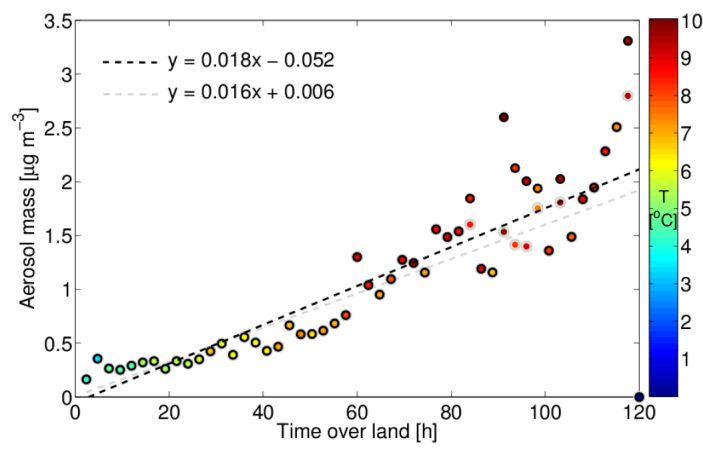

(b)

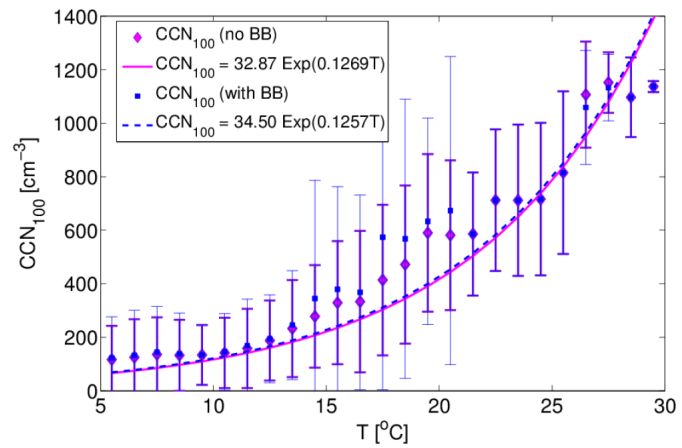

Figure 10. Panel (a): average aerosol total mass $(\leq 500 \mathrm{~nm})$ as a function of air mass time spent over land. Circles with grey borders present all data and circles with black borders data without significant BB influence (i.e., data belonging to mass clusters indicative of biomass burning are not used; for reference, see Fig. 5b). Colors inside circles indicate the average temperature for each point. Dashed grey and black lines show the linear fits $\left(R_{2}=0.84\right.$ for all data; $R_{2}=0.88$ for no $\left.\mathrm{BB}\right)$ to data points along with the fitting equations. Panel (b): average $\mathrm{CCN}_{100}$ concentration calculated from all data (blue squares) and from data without significant BB influence (purple diamonds), plotted as a function of outdoor air temperature, with an exponential fits to the data $\left(R_{2}=0.97\right.$ for all data; $R_{2}=0.98$ for no $\left.\mathrm{BB}\right)$. Bars represent the standard deviation.

As a direct consequence of secondary aerosol formation, the number of the largest particles that are capable of acting as cloud condensation nuclei (CCN) tends to increase. This has been shown by Paasonen et al. (2013) for several sites that were characterized by relatively clean and cold environments and affected by biogenic VOCs. Paasonen et al. (2013) also linked the $\mathrm{CCN}$ concentrations with measured monoterpenes. In their study, they used aerosol number concentrations over the limit of $100 \mathrm{~nm}$ as a proxy for the $\mathrm{CCN}$, which will be here referred to as $\mathrm{CCN}_{100}$.

In Tiksi, the $\mathrm{CCN}_{100}$ concentration also increased as a function of temperature (Fig. 10b). While the average $\mathrm{CCN}_{100}$ concentration remained below $200 \mathrm{~cm}^{-3}$ throughout most of the year, at $>10^{\circ} \mathrm{C}$ an exponential increase as a function of temperature was observed. Paasonen et al. (2013) also showed an increase in $\mathrm{CCN}_{100}$ as a function of temperature with exponential fits for two Finnish, one Canadian, and one Russian Siberian sites. When $\mathrm{CCN}_{100}\left(\mathrm{~cm}^{-3}\right)$ was fitted as a function of temperature $(T)$,

$\mathrm{CCN}_{100}=\alpha \exp (\beta T)$,

Paasonen et al. (2013) obtained $\beta$ values varying between 0.029 and $0.085^{\circ} \mathrm{C}^{-1}$. Here, the $\alpha$ is a fitting variable and has the unit $\mathrm{cm}^{-3}$. Data from Tiksi plotted for a similar temperature range $\left(>5^{\circ} \mathrm{C}\right)$ show an even higher temperature dependence, with a $\beta$ value of $0.126^{\circ} \mathrm{C}^{-1}$ (Fig. 10b). Again, the exclusion of the $\mathrm{BB}$ events did not change the $\beta$ value significantly, yet the data follow the exponential fitting line better when the strong BB events are not included. This confirms a major biological contribution to Tiksi aerosol populations during summer and suggests a strong temperature feedback for the aerosols in Arctic Siberia. Possible reasons for the deviating temperature dependencies observed for the five different sites include differences in the relative importance of other (anthropogenic) sources as well as different vegetation types. Unlike European boreal forest emissions, which are largely dominated by $\alpha$-pinene (Rinne et al., 2000; Tarvainen et al., 2005), emissions from Siberian larches mainly consist of sabinene (Ruuskanen et al., 2007), leading to a different oxidation chemistry and consequently different aerosol yields (e.g., Griffin et al., 1999). In addition to the natural vegetation sources, another temperature-dependent aerosol source in summer Siberia is the intense fire events, which, based on Fig.10b, appear to increase the $\mathrm{CCN}_{100}$ numbers occasionally.

In the context of the entire Tiksi annual temperature range, the maximum average $\mathrm{CCN}_{100}$ concentration of $1130 \mathrm{~cm}^{-3}$ was observed at temperatures $>30^{\circ} \mathrm{C}$ (Fig. 11a). However, these extremely hot days are rare in Tiksi, and only 13 cases were available for calculations. The average $\mathrm{CCN}_{100}$ concentrations were lower in marine than in continental air masses. The increase in $\mathrm{CCN}_{100}$ with temperature was only observed in continental air masses, providing further evidence of the importance of continental biogenic VOC or fire-related sources. However, the comparison of continental and marine air masses is somewhat obscured by the lack of warm Arctic marine air.

The $\mathrm{CCN}_{100}$ concentrations can be compared with the total aerosol number concentrations to identify changes in the aerosol number size distributions. The ratio of these numbers was around 0.5 for most of the year in both air mass types (Fig. 11b). However, during summer (at temperatures above $0{ }^{\circ} \mathrm{C}$ ), this ratio decreased to close to 0.1 in marine air masses, thus indicating an increasing total number concentration caused by the smallest particles. In continental air masses, the $\mathrm{CCN}_{100}$-to-number ratio showed an incremental decrease as a function of temperature in the range of 0 $15^{\circ} \mathrm{C}$, which was followed by a strong increase in $\mathrm{CCN}_{100}$ 

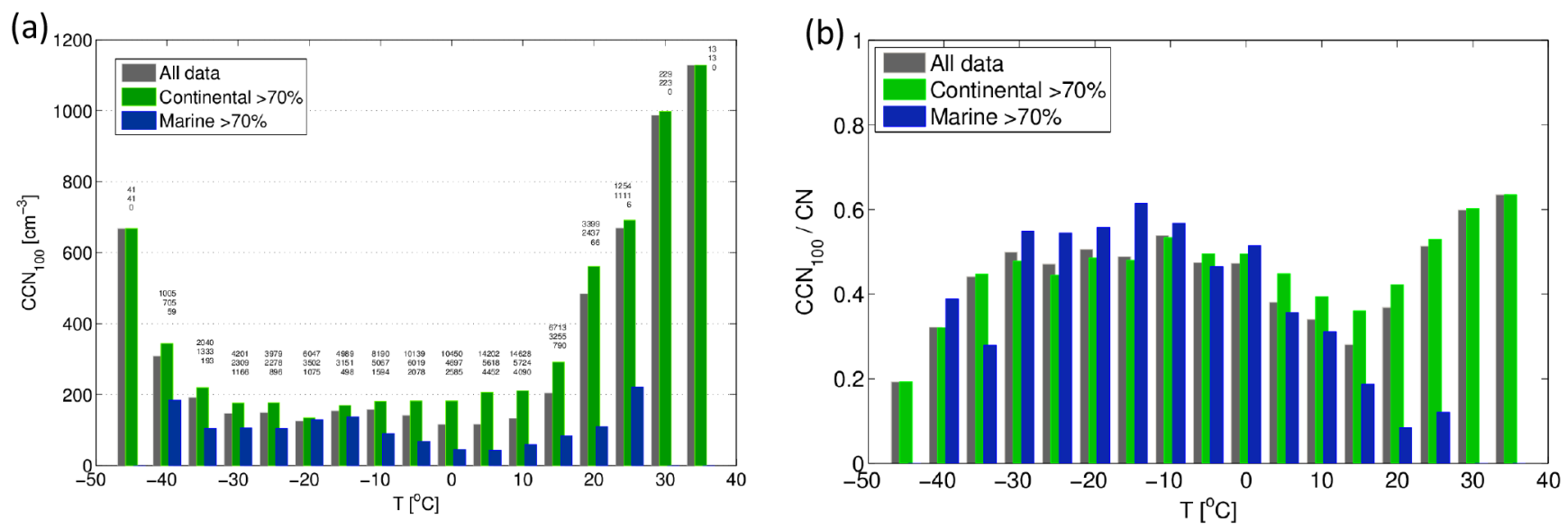

Figure 11. Panel (a): average $\mathrm{CCN}_{100}$ concentration as a function of measurement temperature. Different bars present cases calculated using all data (dark grey), continental data (green), and marine data (blue). Reading from top to bottom, the numbers above each bar show the amount of DMPS data available for each total and for continental and marine cases; these numbers are the same for panel (b). Panel (b): average $\mathrm{CCN}_{100}$ to condensation nuclei $(\mathrm{CN})$ ratio as a function of measurement temperature. Different bars represent cases calculated using all data (dark grey), continental data (green), and marine data (blue).

with temperature. From a global perspective, this result can be compared to those of Andreae (2009), indicating that the $\mathrm{CCN}$ and particle number concentrations and their ratios in Tiksi are well representative of either remote marine or continental sites, depending on the air mass origin.

\subsection{Accumulation of pollutants on calm and cold winter days}

There are many indications in the Tiksi data of a severe pollution occurring during cold and calm weather. This was studied in detail when wind speeds decreased to values close to $1 \mathrm{~m} \mathrm{~s}^{-1}$ (a threshold for data quality checks), resulting in increasing number concentrations (Fig. S7, Supplement). This was particularly true for the Aitken mode particles, indicating influence from local or regional pollution sources, but $\mathrm{CCN}_{100}$ concentrations in the accumulation mode were also elevated during the coldest episodes. As these episodes are likely caused by strong cold-weather inversions and contain episodes lasting for hours or even days, it is not clear if they should be considered as local air pollution events and removed from the analysis or rather as more regional pollution occurring over vast areas in northern Siberia. At wind speeds $>2 \mathrm{~m} \mathrm{~s}^{-1}$, such pollution episodes become rare, and, therefore, in order to exclude them, this limit could be used. However, calm days were common during winter months, and their exclusion also removes a large fraction of wintertime data.

\section{Conclusions}

Aerosols measured in Tiksi show a large seasonal variability in terms of particle size, number, and mass distributions. The monthly median total aerosol number concentration in Tiksi ranges from $184 \mathrm{~cm}^{-3}$ in November to $724 \mathrm{~cm}^{-3}$ in July, with a local maximum in March of $481 \mathrm{~cm}^{-3}$. Nucleation mode particles are frequently observed in Tiksi during early spring and summer, and the formation of these particles is favored in marine air masses. This suggests either a marine source for nucleating vapors or a lower background concentration and thereby a decreased sink for particles and vapors in a coastal zone.

A detailed analysis of secondary particle formation events in Tiksi during 2010-2014 showed that this process takes place on nearly $50 \%$ of days in March and on 30-40\% of days during summer (June-August). Some sporadic events are also observed during the dark winter months, providing evidence that the formation of secondary particles can take place even if there is no photochemistry. Particle formation rates are highest in spring (March-May), while the growth rates are highest in summer (June-August). This suggests that there are effectively two types of particle formation events: (1) the high formation rate events in early spring, originating in the oxidation of anthropogenic emissions accumulated in winter, where the source is essentially the same as for the Arctic haze, and (2) the summertime high growth rate events, which are likely driven by BVOC oxidation in the presence of a weak sink.

The influence of the vast, vegetated Siberian regions on aerosol characteristics is most evident in summer when the number concentration reaches a maximum. This is related to secondary particle formation and growth by biogenic or- 
ganic compounds and to some extent also on biomass burning. By using a cluster analysis, five strong fire events were isolated, showing that biomass burning can have an impact all the way north in the Arctic. The biogenic and biomassburning-related sources increase the particle number but also the mass and the concentrations of cloud condensation nuclei $(\mathrm{CCN})$; they are thus important modulators of the summertime Arctic climate. Increases in the $\mathrm{CCN}$ and particle mass are only seen in continental air masses and have a strong correlation with temperature.

The total mass concentration has a distinct maximum in February-March of $1.72-2.38 \mu \mathrm{g} \mathrm{m}^{-3}$ and two minimums in June $\left(0.42 \mu \mathrm{g} \mathrm{m}^{-3}\right)$ and in September-October $(0.36$ $\left.0.57 \mu \mathrm{g} \mathrm{m}^{-3}\right)$. In winter and spring, the size distributions are dominated by larger accumulation and coarse-mode particles influenced by Arctic haze. Elevated mass concentrations are measured until April, after which another maximum in mass occurs in July-August. The second mass maximum is lower in amplitude and mainly results from increased accumulation mode aerosol mass distributions rather than coarsemode aerosol mass distributions. Additionally, during calm and cold winter periods, severe pollution episodes can occur due to the local inversions leading to an accumulation of particles close to the surface.

The results presented here highlight some of the important mechanisms that control the Russian Arctic aerosol size distributions and sets the stage for quantitative future studies on their source identification.

\section{The Supplement related to this article is available online at doi:10.5194/acp-16-1271-2016-supplement.}

Acknowledgements. This work was supported by the Academy of Finland project "Greenhouse gas, aerosol and albedo variations in the changing Arctic" (project number 269095) and the Academy of Finland Center of Excellence program (project number 272041), the KONE foundation (grant number 46-6817), and a Magnus Ehrnooth foundation grant for "Natural climate feedbacks of aerosols in the Arctic". Data collection, acquisition, transfer, and archiving was supported by the Roshydromet Arctic and Antarctic Research institute and the NOAA Earth Systems Research Laboratory Physical Science Division. We would also like to thank E. D. Volkov and O. V. Dmitrieva for maintaining the measurements in Tiksi year-round.

Edited by: V.-M. Kerminen

\section{References}

Andreae, M. O.: Correlation between cloud condensation nuclei concentration and aerosol optical thickness in remote and polluted regions, Atmos. Chem. Phys., 9, 543-556, doi:10.5194/acp-9-543-2009, 2009.

Andreae, M. O. and Gelencsér, A.: Black carbon or brown carbon? The nature of light-absorbing carbonaceous aerosols, Atmos. Chem. Phys., 6, 3131-3148, doi:10.5194/acp-6-3131-2006, 2006.

Asmi, E., Kivekäs, N., Kerminen, V.-M., Komppula, M., Hyvärinen, A.-P., Hatakka, J., Viisanen, Y., and Lihavainen, H.: Secondary new particle formation in Northern Finland Pallas site between the years 2000 and 2010, Atmos. Chem. Phys., 11, 12959-12972, doi:10.5194/acp-11-12959-2011, 2011.

Asmi, E., Freney, E., Hervo, M., Picard, D., Rose, C., Colomb, A., and Sellegri, K.: Aerosol cloud activation in summer and winter at puy-de-Dôme high altitude site in France, Atmos. Chem. Phys., 12, 11589-11607, doi:10.5194/acp-12-11589-2012, 2012.

Beddows, D. C. S., Dall'Osto, M., and Harrison, R. M.: Cluster Analysis of Rural, Urban, and Curbside Atmospheric Particle Size Data, Environ. Sci. Technol., 43, 4694-4700, doi:10.1021/es803121t, 2009.

Bodhaine, B. A.: Barrow surface aerosol - 1976-1986, Atmos. Environ., 23, 2357-2369, doi:10.1016/0004-6981(89)90249-7, 1989.

Bond, T. C., Doherty, S. J., Fahey, D. W., Forster, P. M., Berntsen, T., DeAngelo, B. J., Flanner, M. G., Ghan, S., Kärcher, B., Koch, D., Kinne, S., Kondo, Y., Quinn, P. K., Sarofim, M. C., Schultz, M. G., Schulz, M., Venkataraman, C., Zhang, H., Zhang, S., Bellouin, N., Guttikunda, S. K., Hopke, P. K., Jacobson, M. Z., Kaiser, J. W., Klimont, Z., Lohmann, U., Schwarz, J. P., Shindell, D., Storelvmo, T., Warren, S. G., and Zenderm C. S.: Bounding the role of black carbon in the climate system: a scientific assessment, J. Geophys. Res.-Atmos., 118, 5380-5552, doi:10.1002/jgrd.50171, 2013.

Bourgeois, Q. and Bey, I.: Pollution transport efficiency toward the Arctic: Sensitivity to aerosol scavenging and source regions, J. Geophys. Res., 116, D08213, doi:10.1029/2010JD015096, 2011.

Chi, X., Winderlich, J., Mayer, J.-C., Panov, A. V., Heimann, M., Birmili, W., Heintzenberg, J., Cheng, Y., and Andreae, M. O.: Long-term measurements of aerosol and carbon monoxide at the ZOTTO tall tower to characterize polluted and pristine air in the Siberian taiga, Atmos. Chem. Phys., 13, 12271-12298, doi:10.5194/acp-13-12271-2013, 2013.

Collaud Coen, M., Weingartner, E., Apituley, A., Ceburnis, D., Fierz-Schmidhauser, R., Flentje, H., Henzing, J. S., Jennings, S. G., Moerman, M., Petzold, A., Schmid, O., and Baltensperger, U.: Minimizing light absorption measurement artifacts of the Aethalometer: evaluation of five correction algorithms, Atmos. Meas. Tech., 3, 457-474, doi:10.5194/amt-3-457-2010, 2010.

Dal Maso, M., Kulmala, M., Riipinen, I., Wagner, R., Hussein, T., Aalto, P. P., and Lehtinen, K. E. J.: Formation and growth of fresh atmospheric aerosols: eight years of aerosol size distribution data from SMEAR II, Hyytiälä, Finland, Boreal Environ. Res., 10, 323-336, 2005.

Draxler, R. R.: HYSPLIT4 user's guide. NOAA Tech. Memo. ERL ARL-230, NOAA Air Resources Laboratory, Silver Spring, MD, USA, 1999. 
Draxler, R. R. and Hess, G. D.: Description of the HYSPLIT_4 modeling system. NOAA Tech. Memo. ERL ARL-224, NOAA Air Resources Laboratory, Silver Spring, MD, USA, 24 pp., 1997.

Draxler, R. R. and Hess, G. D.: An overview of the HYSPLIT_4 modeling system of trajectories, dispersion, and deposition, Aust. Meteor. Mag., 47, 295-308, 1998.

Eckhardt, S., Quennehen, B., Olivié, D. J. L., Berntsen, T. K., Cherian, R., Christensen, J. H., Collins, W., Crepinsek, S., Daskalakis, N., Flanner, M., Herber, A., Heyes, C., Hodnebrog, Ø., Huang, L., Kanakidou, M., Klimont, Z., Langner, J., Law, K. S., Lund, M. T., Mahmood, R., Massling, A., Myriokefalitakis, S., Nielsen, I. E., Nøjgaard, J. K., Quaas, J., Quinn, P. K., Raut, J.-C., Rumbold, S. T., Schulz, M., Sharma, S., Skeie, R. B., Skov, H., Uttal, T., von Salzen, K., and Stohl, A.: Current model capabilities for simulating black carbon and sulfate concentrations in the Arctic atmosphere: a multi-model evaluation using a comprehensive measurement data set, Atmos. Chem. Phys., 15, 9413-9433, doi:10.5194/acp-15-9413-2015, 2015.

Griffin, R. T., Cocker III, D. R., Flagan, R. C., and Seinfeld, J. H.: Organic aerosol formation from the oxidation of biogenic hydrocarbons, J. Geophys. Res., 104, 3555-3567, 1999.

Guenther, A., Karl, T., Harley, P., Wiedinmyer, C., Palmer, P. I., and Geron, C.: Estimates of global terrestrial isoprene emissions using MEGAN (Model of Emissions of Gases and Aerosols from Nature), Atmos. Chem. Phys., 6, 3181-3210, doi:10.5194/acp-63181-2006, 2006.

Hamed, A., Korhonen, H., Sihto, S.-L., Joutsensaari, J., Järvinen, H., Petäjä, T., Arnold, F., Nieminen, T., Kulmala, M., Smith, J. N., Lehtinen, K. E. J., and Laaksonen, A.: The role of relative humidity in continental new particle formation, J. Geophys. Res., 116, D03202, doi:10.1029/2010JD014186, 2011.

Heintzenberg, J., Birmili, W., Theiss, D., and Kisilyakhov, Y.: The atmospheric aerosol over Siberia, as seen from the $300 \mathrm{~m}$ ZOTTO tower, Tellus, 60B, 276-285, 2008.

Heintzenberg, J., Birmili, W., Otto, R., Andreae, M. O., Mayer, J.C., Chi, X., and Panov, A.: Aerosol particle number size distributions and particulate light absorption at the ZOTTO tall tower (Siberia), 2006-2009, Atmos. Chem. Phys., 11, 87038719, doi:10.5194/acp-11-8703-2011, 2011.

Hienola, A. I., Pietikäinen, J.-P., Jacob, D., Pozdun, R., Petäjä, T., Hyvärinen, A.-P., Sogacheva, L., Kerminen, V.-M., Kulmala, M., and Laaksonen, A.: Black carbon concentration and deposition estimations in Finland by the regional aerosol-climate model REMO-HAM, Atmos. Chem. Phys., 13, 4033-4055, doi:10.5194/acp-13-4033-2013, 2013.

Hinds, W. C.: Aerosol Technology: Properties, Behaviour and Measurement of Airborne Particles, 2nd Edn., John Wiley, New York, USA, 1999.

Järvinen, E., Virkkula, A., Nieminen, T., Aalto, P. P., Asmi, E., Lanconelli, C., Busetto, M., Lupi, A., Schioppo, R., Vitale, V., Mazzola, M., Petäjä, T., Kerminen, V.-M., and Kulmala, M.: Seasonal cycle and modal structure of particle number size distribution at Dome C, Antarctica, Atmos. Chem. Phys., 13, 7473-7487, doi:10.5194/acp-13-7473-2013, 2013.

Kirchstetter, T. W. and Thatcher, T. L.: Contribution of organic carbon to wood smoke particulate matter absorption of solar radiation, Atmos. Chem. Phys., 12, 6067-6072, doi:10.5194/acp-126067-2012, 2012.
Kulmala, M., Dal Maso, M., Mäkelä, J. M., Pirjola, L., Väkevä, M., Aalto, P., Miikkulainen, P., Hämeri, K., and O'Dowd, C.: On the formation, growth, and composition of nucleation mode particles, Tellus B, 53, 479-490, doi:10.1034/j.1600-0889.2001.d0133.x, 2001.

Laakso, L., Hussein, T., Aarnio, P., Komppula, M., Hiltunen, V., Viisanen, Y., and Kulmala, M.: Diurnal and annual characteristics of particle mass and number concentrations in urban, rural and Arctic environments in Finland, Atmos. Environ., 37, 26292641, 2003.

Laakso, L., Petäjä, T., Lehtinen, K. E. J., Kulmala, M., Paatero, J., Hõrrak, U., Tammet, H., and Joutsensaari, J.: Ion production rate in a boreal forest based on ion, particle and radiation measurements, Atmos. Chem. Phys., 4, 1933-1943, doi:10.5194/acp-41933-2004, 2004.

Liu, X., Easter, R. C., Ghan, S. J., Zaveri, R., Rasch, P., Shi, X., Lamarque, J.-F., Gettelman, A., Morrison, H., Vitt, F., Conley, A., Park, S., Neale, R., Hannay, C., Ekman, A. M. L., Hess, P., Mahowald, N., Collins, W., Iacono, M. J., Bretherton, C. S., Flanner, M. G., and Mitchell, D.: Toward a minimal representation of aerosols in climate models: description and evaluation in the Community Atmosphere Model CAM5, Geosci. Model Dev., 5, 709-739, doi:10.5194/gmd-5-709-2012, 2012.

Mauritsen, T., Sedlar, J., Tjernström, M., Leck, C., Martin, M., Shupe, M., Sjogren, S., Sierau, B., Persson, P. O. G., Brooks, I. M., and Swietlicki, E.: An Arctic CCN-limited cloud-aerosol regime, Atmos. Chem. Phys., 11, 165-173, doi:10.5194/acp-11165-2011, 2011.

Mitchell, J. M.: Visual range in the polar regions with particular reference to the Alaskan Arctic, J. Atmos. Terr. Phys., 17, 195211, 1957.

Paasonen, P., Asmi, A., Petäjä, T., Kajos, M. K., Äijälä, M., Junninen, H., Holst, T., Abbatt, J. P. D., Arneth, A., Birmili, W., van der Gon, H. D., Hamed, A., Hoffer, A., Laakso, L., Laaksonen, A., Leaitch, W. R., Plass-Dülmer, C. Pryor, S. C., Räisänen, P., Swietlicki, E., Wiedensohler, A., Worsnop, D. R., Kerminen, V.-M., and Kulmala, M.: Warming-induced increase in aerosol number concentration likely to moderate climate change, Nat. Geosci., 6, 438-442, doi:10.1038/ngeo1800, 2013.

Petzold, A., Ogren, J. A., Fiebig, M., Laj, P., Li, S.-M., Baltensperger, U., Holzer-Popp, T., Kinne, S., Pappalardo, G., Sugimoto, N., Wehrli, C., Wiedensohler, A., and Zhang, X.-Y.: Recommendations for reporting "black carbon" measurements, Atmos. Chem. Phys., 13, 8365-8379, doi:10.5194/acp-13-83652013, 2013.

Quinn, P. K., Miller, T. L., Bates, T. S., Ogren, J. A., Andrews, E., and Shaw, G. E.: A 3-year record of simultaneously measured aerosol chemical and optical properties at Barrow, Alaska, J Geophys. Res.-Atmos., 107, 4130, doi:10.1029/2001JD001248, 2002.

Richter-Menge, J., Overland, J., Proshutinsky, A., Romanovsky, V., Bengtsson, L., Brigham, L., Dyurgerov, M., Gascard, J. C., Gerland, S., Graversen, R., Haas, C., Karcher, M., Kuhry, P., Maslanik, J., Melling, H., Maslowski, W., Morison, J., Perovich, D., Przybylak, R., Rachold, V., Rigor, I., Shiklomanov, A., Stroeve, J., Walker, D., and Walsh J.: State of the Arctic Report. NOAA OAR Special Report, NOAA/OAR/PMEL, Seattle, WA, USA, 36 pp., 2006. 
Rinne, J., Hakola, H., Laurila, T. and Rannik, U: Canopy scale monoterpene emissions of pinus sylvestris dominated forests, Atmos. Environ., 34, 1099-1107, doi:10.1016/S13522310(99)00335-0, 2000.

Ruuskanen, T. M., Kajos, M., Hellén, H., Hakola, H., Tarvainen, V., and Rinne, J.: Volatile organic compound emissions from Siberian larch, Atmos. Environ., 41, 5807-5812, 2007.

Saarikoski, S., Mäkelä, T., Hillamo, R., Aalto, P. P., Kerminen, V.-M., and Kulmala, M.: Physico-chemical characterization and mass closure of size-segregated atmospheric aerosols in Hyytiälä, Finland, Boreal Env. Res., 10, 385-400, 2005.

Shindell, D. and Faluvegi, G.: Climate response to regional radiative forcing during the twentieth century, Nature Geosci., 2, 294-300, 2009.

Sogacheva, L., Saukkonen, L., Nilsson, E. D., Dal Maso, M., Schultz, D. M., De Leeuw, G., and Kulmala, M.: New aerosol particle formation in different synoptic situations at Hyytiälä Southern Finland, Tellus, 60B, 485-494, 2008.

Stock, M., Ritter, C., Aaltonen, V., Aas, W., Handorff, D., Herber, A., Treffeisen, R., and Dethloff, K.: Where does the optically detectable aerosol in the European Arctic come from?, Tellus B, 66, 21450, doi:10.3402/tellusb.v66.21450, 2014.

Stohl, A., Klimont, Z., Eckhardt, S., Kupiainen, K., Shevchenko, V. P., Kopeikin, V. M., and Novigatsky, A. N.: Black carbon in the Arctic: the underestimated role of gas flaring and residential combustion emissions, Atmos. Chem. Phys., 13, 8833-8855, doi:10.5194/acp-13-8833-2013, 2013.

Stolzenburg, M.: An Ultrafine Aerosol Size Distribution Measuring System, PhD thesis, Mechanical Engineering Department, University of Minnesota, USA, 1988.

Tarvainen, V., Hakola, H., Hellén, H., Bäck, J., Hari, P., and Kulmala, M.: Temperature and light dependence of the VOC emissions of Scots pine, Atmos. Chem. Phys., 5, 989-998, doi:10.5194/acp-5-989-2005, 2005.

Tunved, P., Hansson, H.-C., Kulmala, M., Aalto, P., Viisanen, Y., Karlsson, H., Kristensson, A., Swietlicki, E., Dal Maso, M., Ström, J., and Komppula, M.: One year boundary layer aerosol size distribution data from five nordic background stations, Atmos. Chem. Phys., 3, 2183-2205, doi:10.5194/acp-3-2183-2003, 2003.

Tunved, P., Hansson, H.-C., Kerminen, V.-M., Ström, J., Dal Maso, M., Lihavainen, H., Viisanen, Y., Aalto, P. P., Komppula, M., and Kulmala, M.: High natural aerosol loading over boreal forests, Science, 312, 261-263, 2006.
Tunved, P., Ström, J., and Krejci, R.: Arctic aerosol life cycle: linking aerosol size distributions observed between 2000 and 2010 with air mass transport and precipitation at Zeppelin station, Ny-Ålesund, Svalbard, Atmos. Chem. Phys., 13, 3643-3660, doi:10.5194/acp-13-3643-2013, 2013.

Uttal, T., Makshtas, A., and Laurila, T.: The Tiksi International Hydrometeorological Observatory - An Arctic Members Partnership, WMO Bulletin, 62, 22-26, 2013.

Väänänen, R., Kyrö, E.-M., Nieminen, T., Kivekäs, N., Junninen, H., Virkkula, A., Dal Maso, M., Lihavainen, H., Viisanen, Y., Svenningsson, B., Holst, T., Arneth, A., Aalto, P. P., Kulmala, M., and Kerminen, V.-M.: Analysis of particle size distribution changes between three measurement sites in northern Scandinavia, Atmos. Chem. Phys., 13, 11887-11903, doi:10.5194/acp13-11887-2013, 2013.

Viskari, T., Asmi, E., Virkkula, A., Kolmonen, P., Petäjä, T., and Järvinen, H.: Estimation of aerosol particle number distribution with Kalman Filtering - Part 2: Simultaneous use of DMPS, APS and nephelometer measurements, Atmos. Chem. Phys., 12, 11781-11793, doi:10.5194/acp-12-11781-2012, 2012.

Walsh, J. E. and Chapman, W. L.: Arctic cloud-radiationtemperature associations in observational data and atmospheric reanalysis, J. Climate, 11, 3030-3045, 1998.

Weller, R., Schmidt, K., Teinilä, K., and Hillamo, R.: Natural new particle formation at the coastal Antarctic site Neumayer, Atmos. Chem. Phys., 15, 11399-11410, doi:10.5194/acp-1511399-2015, 2015.

Wiedensohler, A.: Die bipolare Diffusionsaufladung von Partikeln in chemisch trägen Reinstgasen, $\mathrm{PhD}$ thesis, University of Duisburg, Germany, 1989.

Wiedensohler, A., Birmili, W., Nowak, A., Sonntag, A., Weinhold, K., Merkel, M., Wehner, B., Tuch, T., Pfeifer, S., Fiebig, M. Fjäraa, A. M., Asmi, E., Sellegri, K., Depuy, R., Venzac, H., Villani, P., Laj, P., Aalto, P., Ogren, J. A., Swietlicki, E., Williams, P., Roldin, P., Quincey, P., Hüglin, C., Fierz-Schmidhauser, R., Gysel, M., Weingartner, E., Riccobono, F., Santos, S., Grüning, C., Faloon, K., Beddows, D., Harrison, R., Monahan, C., Jennings, S. G., O’Dowd, C. D., Marinoni, A., Horn, H.-G., Keck, L., Jiang, J., Scheckman, J., McMurry, P. H., Deng, Z., Zhao, C. S., Moerman, M., Henzing, B., de Leeuw, G., Löschau, G., and Bastian, S.: Mobility particle size spectrometers: harmonization of technical standards and data structure to facilitate high quality long-term observations of atmospheric particle number size distributions, Atmos. Meas. Tech., 5, 657-685, doi:10.5194/amt5-657-2012, 2012 